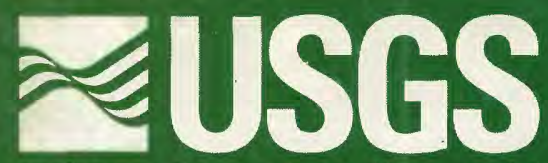

In cooperation with the

OHpo49

City of Delphos, Ohio

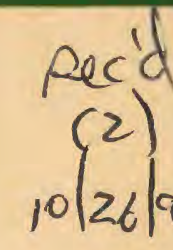

Background Hydrogeologic Data, Water Quality, and Aquifer Characteristics,

Western Allen County, Ohio

Water-Resources Investigations Report 99-4146

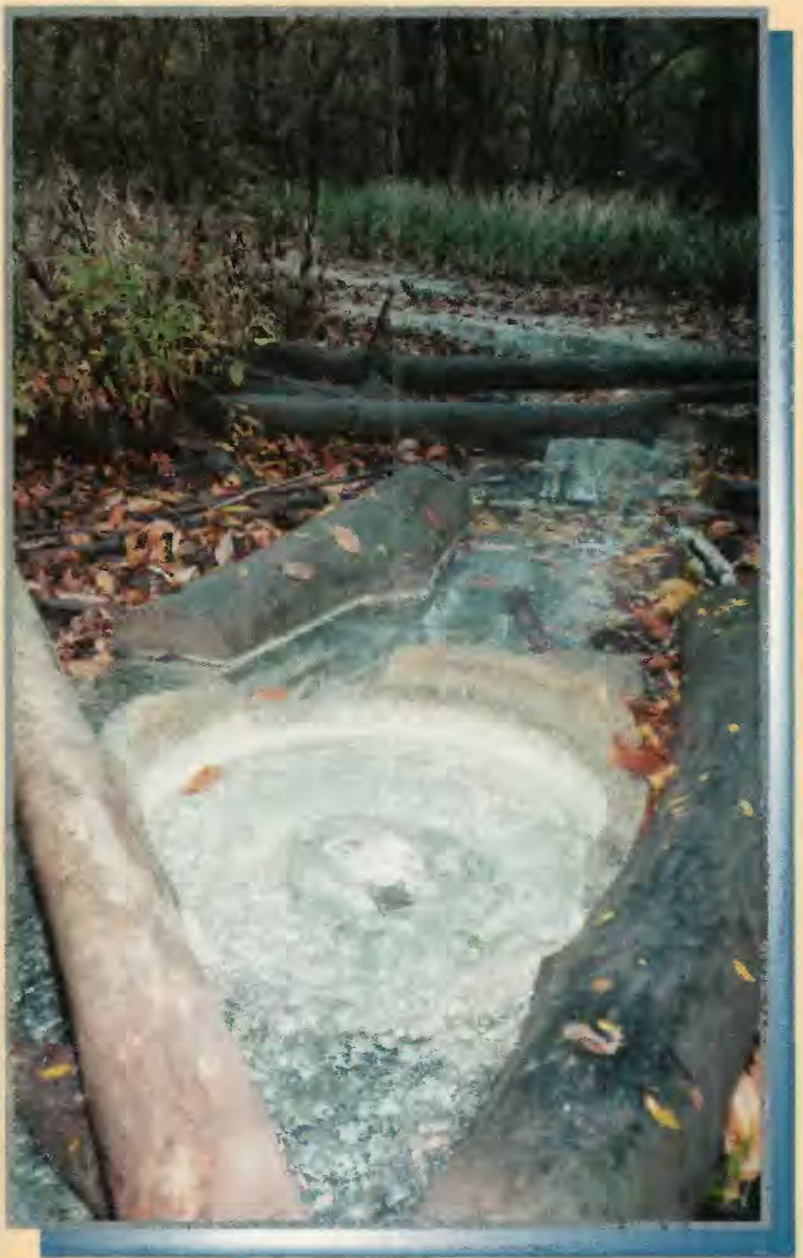

U.S. Department of the Interior

U.S. Geological Survey 
Cover photo: View of Kendrick Woods Metro Park spring, Amanda Township, Allen County, Ohio.

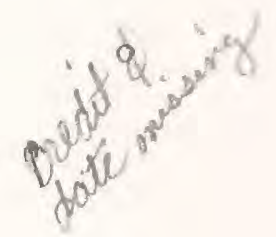


U.S. Department of the Interior

U.S. Geological Survey

\section{Background Hydrogeologic Data, Water Quality, and Aquifer \\ Characteristics, Western Allen County, Ohio}

By Rodney A. Sheets

Water-Resources Investigations Report 99-4146

In cooperation with the

City of Delphos, Ohio 


\section{U.S. DEPARTMENT OF THE INTERIOR \\ BRUCE BABBITT, Secretary}

\section{U.S. GEOLOGICAL SURVEY}

Charles G. Groat, Director

Any use of trade, product, or firm names is for descriptive purposes only and does not constitute endorsement by the U.S. Government.

For additional information write to

\section{District Chief}

U.S. Geological Survey

6480 Doubletree Avenue

Columbus, Ohio 43229-1111

Copies of this report can be purchased from:

U.S. Geological Survey

Branch of Information Services

Box 25286

Denver, CO 80225-0286

Columbus, Ohio

1999 


\section{CONTENTS}

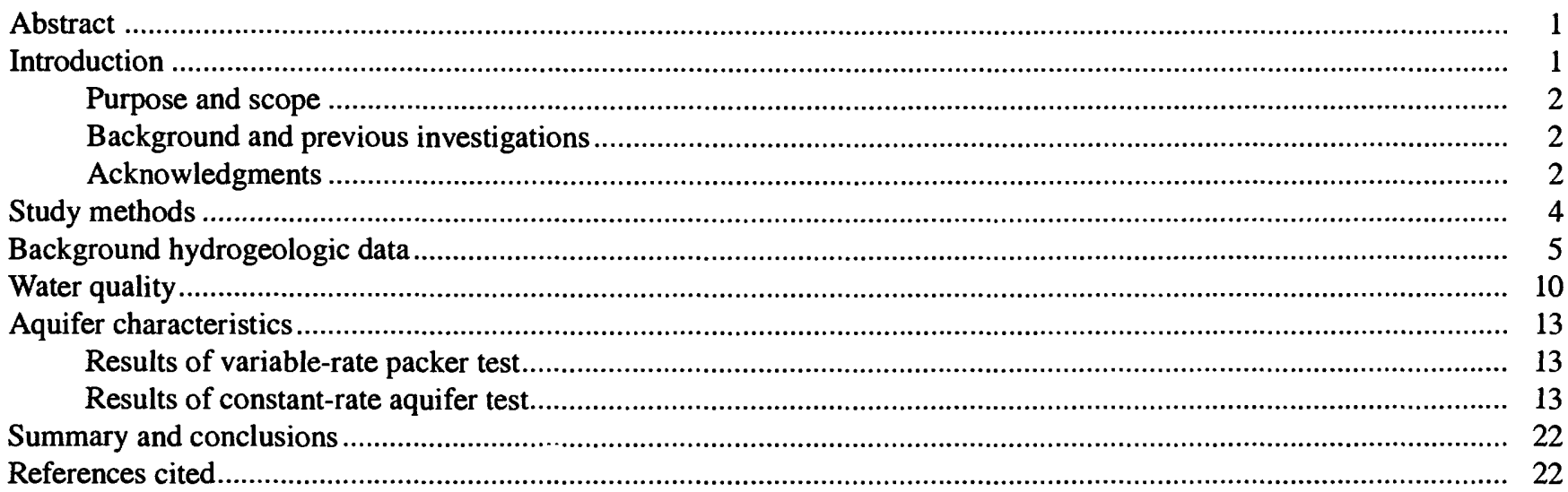

\section{FIGURES}

1. Map showing location of study area and wells used in this study ................................................................. 3

2. Graph showing specific capacity as a function of well depth................................................................ 8

3. Borehole geophysical logs and interpreted stratigraphic section of well AL-85............................................. 9

4. Polar plots of azimuthal electromagnetic surveys done $200 \mathrm{ft}$ north of well AL-85 .......................................... 10

5-7. Graphs showing the relation of selected water-quality measurements to well depth:

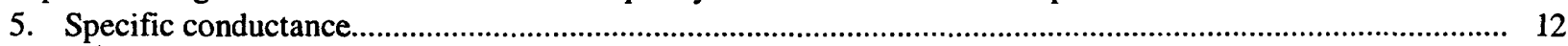

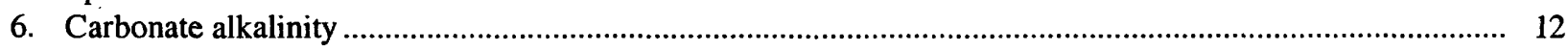

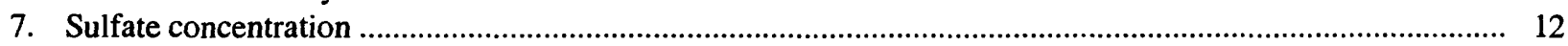

8-21. Graphs showing:

8. Water levels for wells AL-64, AL-85 and AL-125 during a variable-rate packer test on well AL-64............ 14

9. Water levels for wells completed in glacial and upper carbonate aquifer during a variable-rate packer test in well AL-64...................................................................................................................... 14

10. Water levels for well AL-64 and barometric pressure during the step- and constant-rate tests at well AL-85.. 15

11. Barometric pressure as a function of water level for well AL-64, for a period of no pumping ...................... 16

12. Time-drawdown data and Theis type curve for well AL-64 ........................................................... 16

13. Barometric pressure as a function of water level for well AL-65, for a period of no pumping ..................... 17

14. Time-drawdown data and Theis-type curve for well AL-65 ................................................................ 17

15. Time-drawdown data and Cooper and Jacob type curve for AL-65 ................................................. 18

16. Barometric pressure and water levels for two shallow wells completed in sand lenses within the glacial till.. 18

17. Water levels for well AL-101 and barometric pressure for a period including pumping at well AL-85......... 19

18. Normalized drawdown for well AL-101 during the step test and constant-rate test on well AL-85 .............. 19

19. Normalized time-drawdown data for AL-101 during constant pumping at well AL-85 ............................. 20

20. Distance-drawdown graph for constant-rate test of well AL-85.............................................................. 21

21. Gage height of flume installed at AL-125 during the step-pumping and constant-rate test at well AL-85...... 21

\section{TABLES}

1. Summary of general data for wells and AL-125 (Kendrick Woods Metro Park spring) ..................................... 6

2. Summary of water-quality analyses for selected wells and AL-125 (Kendrick Woods Metro Park spring) .......... 11 
CONVERSION FACTORS, VERTICAL DATUM, AND ABBREVIATIONS

\begin{tabular}{|c|c|c|}
\hline Multiply & By & To obtain \\
\hline inches (in.) & 25.4 & millimeters (mm) \\
\hline feet $(\mathrm{ft})$ & 0.3048 & meters $(\mathrm{m})$ \\
\hline miles (mi) & 1.609 & kilometers $(\mathbf{k m})$ \\
\hline square miles $\left(\mathrm{mi}^{2}\right)$ & 12.590 & square kilometers $\left(k^{2}\right)$ \\
\hline gallons (gal) & $3.785 \mathrm{E}-3$ & cubic meters $\left(m^{3}\right)$ \\
\hline gallons per minute ( $\mathrm{gal} / \mathrm{min}$ ) & 5.3 & cubic meters per day $\left(m^{2}+d\right)$ \\
\hline gallons per minute per $\mathrm{ft}[(\mathrm{gal} / \mathrm{min}) / \mathrm{ft}])$ & 17.89 & square meters per day $\left(m^{2} t d\right)$ \\
\hline gallons per day per $\mathrm{ft}[(\mathrm{gal} / \mathrm{d}) / \mathrm{ft}])$ & $1.242 \mathrm{E}-2$ & square meters per day $\left(\mathrm{m}^{2} / \mathrm{d}\right)$ \\
\hline pounds per square inch $\left(\mathrm{lb} / \mathrm{in}^{2}\right)$ & $7.031 \mathrm{E}-2$ & kilograms per square centimeter $\left(\mathrm{kg} / \mathrm{cm}^{2}\right)$ \\
\hline degrees Fahrenheit $\left({ }^{\circ} \mathrm{F}\right)$ & $5(\mathrm{~F}-32) / 9$ & degrees Celsius 9 \\
\hline
\end{tabular}

Sea level: In this report, "sea level" refers to the National Geodetic Vertical Datum of 1929 (NGVD of 1929) - a geodetic datum derived from a general adjustment of the first-order level nets of both the United States and Canada, formerly called Sea Level Datum of 1929.

Abbreviated water-quality units used in this report: Chemical concentration is given in milligrams per liter $(\mathrm{mg} / \mathrm{L})$ or micrograms per liter $(\mu \mathrm{g} / \mathrm{l})$. These units express the concentration of chemical constituents in solution as weight (milligrams or micrograms) of solute per unit volume (liter) of solvent (water). Concentration of tritium, a radioisotope of hydrogen, is given in picocuries per liter $(\mathrm{pCi} / \mathrm{L})$. Specific conductance of water is expressed in microsiemens per centimeter at 25 degrees Celckius $(\mu \mathrm{S} / \mathrm{cm})$.

$\hat{s}$

\section{GLOSSARY}

Anisotropy. The condition under which one or more of the hydraulic properties of an aquifer vary according to direction.

Aquifer, confined. An aquifer that is overlain by a confining bed and whose water level rises above the confining bed. The confining bed has a significantly lower hydraulic conductivity than the aquifer.

Aquifer test. A test made by pumping a well for a period of time and observing the change in hydraulic head in the aquifer. An aquifer test may be used to deterfinine the capacity of the well and the hydraulic characteristics of the aquifer.

Borehole geophysics. The general field of geophysics developed on the basis of data collected by lowering of various probes into a well.

Electromagnetic conductivity. A method of measuring the induced electrical field in the earth to determine the ability of the earth to conduct electricity. Electromagnetic conductivity is the inverse of electrical resistivity.

Flume. A device placed in a stream of water to measure the volume or rate of flow.

Glacial till. A glacial deposit composed mostly of unsorted sand, silt, clay, and boulders and laid down directly by the melting ice.

Gradient, hydraulic. In an aquifer, the rate of change of pressure head per unit of distance of flow at a given point and in a given direction.

Ground water, perched. The water in an isolated saturated zone within the unsaturated zone. It is the result of the presence of a layer of material of low hydraulic conductivity.

Lineation. A near-linear feature on the ground surface often associated with subsurface fractures.

Observation well. A nonpumping well in which the water level is measured.

Packer test. An aquifer test performed on a well instrumented with a packer, a device designed to seal the borehole and isolate specific water-bearing zones. 
Pressure head. Hydrostatic pressure expressed as the height of a column of water that the pressure can support (usually expressed with reference to a specific level such as land surface).

Specific capacity. The yield of a well per unit of drawdown.

Step test. A specific kind of aquifer test used to examine the performance of wells having turbulent flow and to determine the specific capacity of the well at various discharge rates.

Storage coefficient. The volume of water an aquifer releases from or takes into storage per unit volume of the aquifer per unit change in head. Also known as storativity.

Stratigraphy. The arrangement of geologic layers, especially as to geographic position and chronologic order of sequence.

Theis equation. An equation for the flow of ground water in a fully confined aquifer.

Transmissivity. The rate at which water is transmitted through a unit width of an aquifer under a unit hydraulic gradient.

Tritium. A radioactive isotope of hydrogen. 


\title{
Background Hydrogeologic Data, Water Quality, and Aquifer Characteristics, Western Allen County, Ohio
}

\author{
by Rodney A. Sheets
}

\section{ABSTRACT}

The carbonate aquifer of northwestern Ohio is used extensively for domestic, industrial, and public water supplies. The City of Delphos, Ohio, would like to expand its current ground-water supplies with wells completed in the carbonate aquifer in Amanda Township, Allen County. Surface- and borehole-geophysical surveys were used to determine thickness of the glacial till overlying the carbonate bedrock and the extent and orientation of fractures in the carbonate bedrock.

Water-quality and water-level data were collected before and during a constant-rate aquifer test to determine general hydrogeologic characteristics of the area. Previous drilling and borehole geophysical data indicated water-bearing fractures in the aquifer at depths greater than 190 feet. Aerial photographs and surface geophysical data indicate northwest-southeast-trending features that might be related to near-surface fracturing of the overburden. Water quality and tritium data show that recharge rates through the glacial till covering the carbonate bedrock are slow and that sand lenses within the till contain water of different quality than that within the carbonate aquifer. The potentiometric surface of the carbonate aquifer is virtually flat (nearly zero gradient), but water levels in paired wells indicate that recharge takes place near a proposed well field and that regional discharge is to the Auglaize River, east of the proposed well field.
A constant-rate aquifer test on a well in the proposed well field yielded an average transmissivity of the carbonate aquifer of approximately 28,000 to 36,000 gallons per day per foot and an average storage coefficient of $3 \times 10^{-5}$. The aquifer test was prematurely terminated because of a decrease in flow from a nearby spring that flows into and forms a wetland. Water quality of the spring more closely matches that of water from the carbonate aquifer than the water from the glacial aquifer. Historical accounts, response of spring flow to pumping of nearby wells, and proximity of several abandoned wells all suggest that the spring is actually an abandoned flowing artesian well.

\section{INTRODUCTION}

The carbonate-aquifer system of ngrthwest Ohio is used extensively as a source of public, industrial, and domestic water supplies. The hydraulic characteristics of the carbonate-aquifer system, as well as the quality of water in the system, generally vary with geologic unit and intensity of fracturing.

In order to meet increasing demands for water supply, the City of Delphos, Ohio, planned to develop a well field in the carbonate-aquifer system beginning in 1998. The proposed well field is in Amanda Township, Allen County (fig. 1). Prior to developing a sustained water source, hydrogeologic characterization of the well-field area was needed to determine the potential effect of pumping on local domestic and agricultural 
wells and on the flow from a spring ${ }^{1}$ in Kendrick Woods Metro Park (fig. 1).

To better understand the regional effects of pumping, the U.S. Geological Survey (USGS), in cooperation with the City of Delphos, conducted a series of aquifer tests in the vicinity of the proposed well field. The USGS provided a regional context for the aquifer-test results by sampling selected wells in advance of the aquifer tests to obtain data on the natural range of ground-waterquality constituent concentrations and recharge age of ground water.

\section{Purpose and Scope}

The purpose of this report is to describe the ground-water hydrology of the proposed wellfield area and present the results of aquifer tests that were done at the proposed well field. Data collected during the study include ground-water levels before, during, and after the aquifer tests; chemical analyses of samples collected before the aquifer tests; and flow rates of a nearby spring. Background hydrogeologic data, including water levels and water-quality analyses, also are presented. The water-level and flow data are analyzed with respect to pumping rates from the proposed well field.

\section{Background and Previous Investigations}

The proposed well field area is approximately $5 \mathrm{mi}$ south of the City of Delphos, in Amanda Township, Allen County (fig. 1). Approximately $30-40 \mathrm{ft}$ of glacial till (a heterogeneous mixture of clay, silt, and sand and gravel, with interspersed sand lenses) overlies the Silurian Tymochtee Dolomite or Greenfield Dolomite. Some of the sand lenses can yield enough water for individual household supplies; however, drillers commonly complete household wells just a few feet below the top of the carbonate aquifer.

\footnotetext{
The "Glossary of Geology" (Bates and Jackson, 1987) defines a spring as "A place where ground water flows naturally from a rock or the soil onto the land surface ...." The mentioned spring may be an abandoned well; it will be described later in this report.
}

Larger water-supply wells, such as those used for agricultural production, are usually/completed at least $100 \mathrm{ft}$ into the carbonate aquifer.

Two wells are located at the proposed well field, denoted AL-64 and AL-85 in figure 1, but also referred to as "Heidlebaugh 1" and "Heidlebaugh 2" by Eagon \& Associates, Inc. (1993). Fracture-trace analysis from aerial photographs was used to determine the siting of these wells (Michael Gross, Eagon \& Associates, Inc., oral commun., 1998). Wells AL-64 and AL-85 are completed as 8-in.-diameter open holes in the carbonate aquifer to depths of 300 and $315 \mathrm{ft}$, respectively. Each well was to be used as either a pumping well or an observation well. The carbonate aquifer is covered by approximately $35 \mathrm{ft}$ of glacial till, which was sealed off by steel casing.

Eagon \& Associates, Inc. (1993) conducted a step test and a subsequent 12-hour constant-rate aquifer test on well AL-64. Flow rates for the step test ranged from 91 to $412 \mathrm{gal} / \mathrm{min}$ and the constant rate was $372 \mathrm{gal} / \mathrm{min}$. AL-65 (also referred to as "well 61" by Eagon \& Associates, Inc., 1993), located at Kendrick Woods Metro Park (fig. 1), exhibited the largest drawdown (3.8 ft) among the domestic wells measured during the test. Timedelayed drawdown was indicated by data from three domestic wells measured during and after pumping (wells 7A, 36 and 38S; Eagon \& Associates, Inc., 1993). On the basis of analysis of timedrawdown data from selected wells, transmissivities for the carbonate aquifer ranged from 20,000 to $43,000(\mathrm{gal} / \mathrm{d}) / \mathrm{ft}$, and storage coefficients ranged from $9 \times 10^{-6}$ to $4 \times 10^{-5}$, depending on the interpretation technique and wells used in the analysis (Eagon \&) Associates, Inc., 1993; Bennett \& Williams Environmental Consultants, Inc., 1993).

\section{Acknowledgments}

The author extends thanks the citizens of Amanda Township and Kevin Haver of the Kendrick Woods Metro Park for their cooperation and interest in this study. Richard Schuck of the City of Delphos also provided logistical support that greatly aided this project.

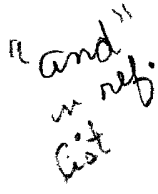




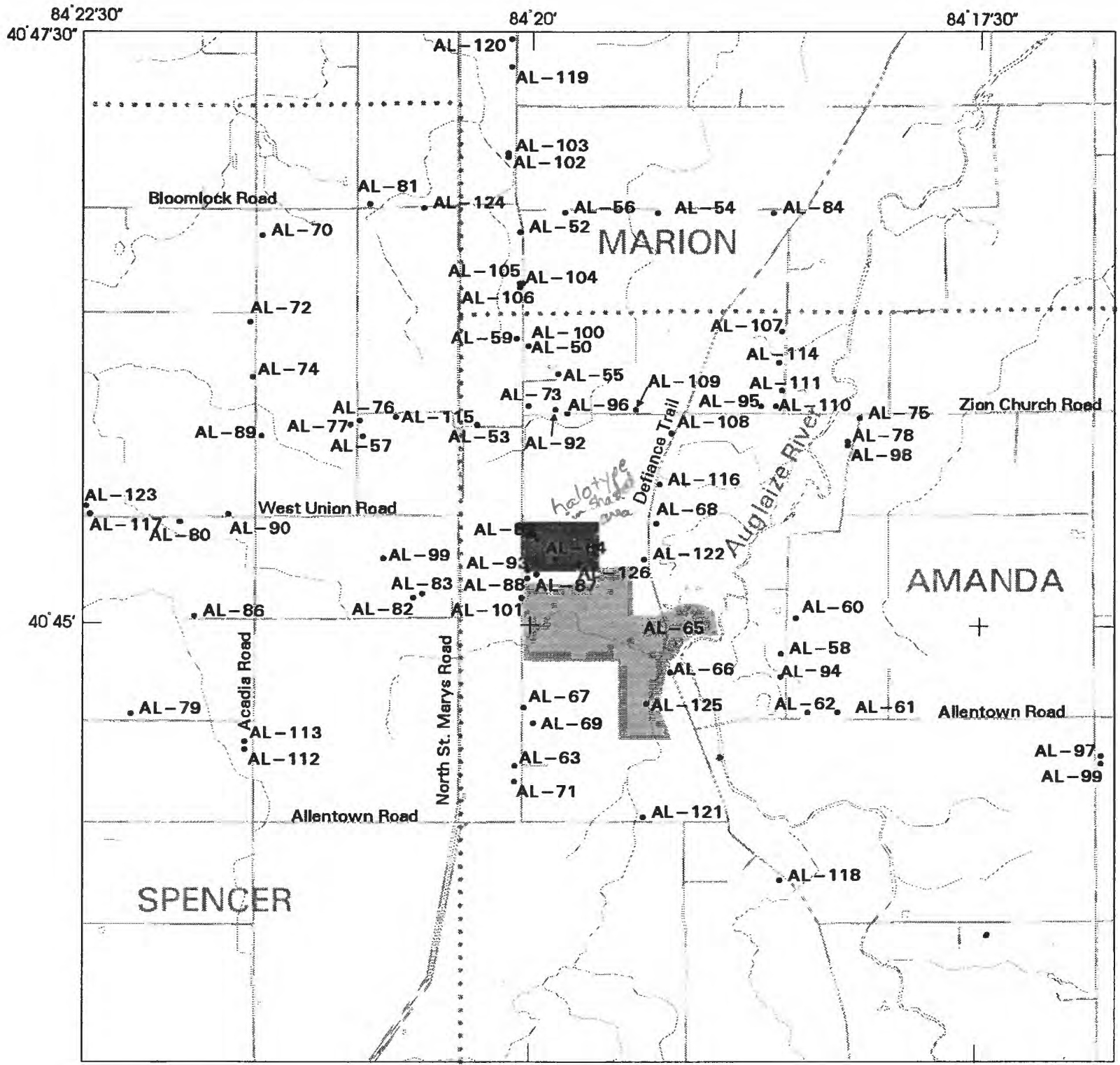

Base from U.S. Geological Survey, 1:100,000 Digital Data

Albers Equal-Area Conic Projection

Standard parallels $29^{\circ} 30^{\circ}$ and $45^{\circ} 30^{\circ}$, central meridian-86 $00^{\prime}$
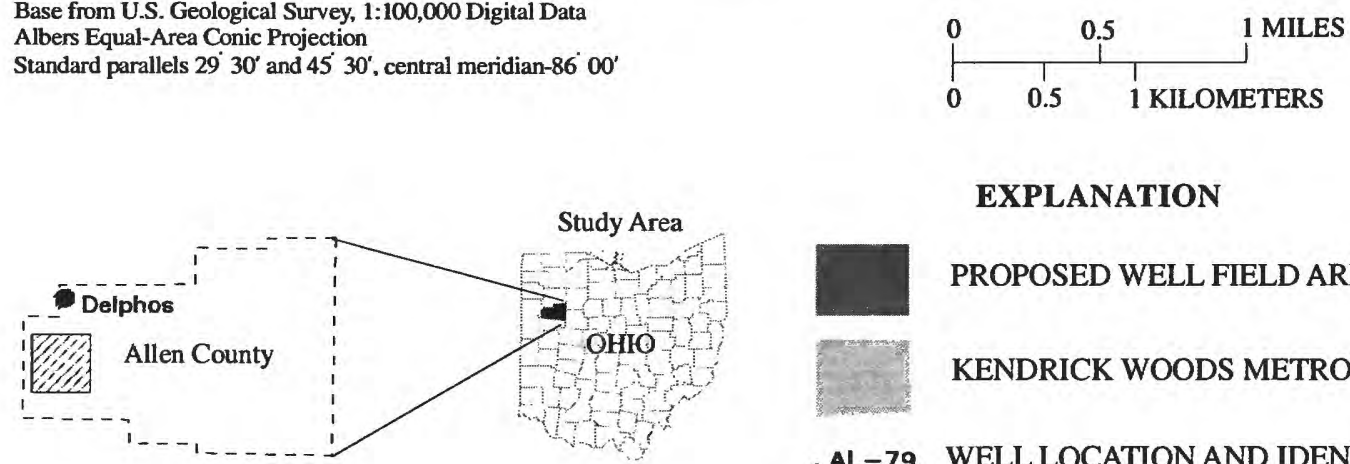

EXPLANATION

PROPOSED WELL FIELD AREA

KENDRICK WOODS METRO PARK

.AL-79 WELL LOCATION AND IDENTIFIER

Figure 1. Location of study area and wells used in this study. 


\section{STUDY METHODS}

During 1998, USGS personnel collected various types of data in and around the proposed well field to help interpret the hydrogeologic setting. These data included water levels in wells, specificcapacity tests on domestic wells, an aquifer test of one well, geophysical logs, water-quality data, and surface geophysical surveys. The following paragraphs describe the data-collection methods used during this study, including those used during the aquifer test.

Depths to water in wells from a measuring point, usually at the top of the casing, were measured in wells with an electric or wetted-steel tape. Land-surface elevations were obtained by locating the wells on USGS 7.5-minute quadrangle maps. Elevations of the proposed pumping well (AL-64) and observation well (AL-85) were surveyed by the City of Delphos. Latitude and longitude were determined either by Global Positioning System or determined from USGS 7.5-minute quadrangle maps. These data, along with relative accuracies of the measurements, were entered into the USGS Ground-Water Site Inventory (GWSI) data base.

If drillers' logs (obtained from Ohio Department of Natural Resources) were available for the well, information on completion depth, construction date, pump setting, and other data were entered into the USGS GWSI data base, along with data gathered in the field. If a well log was not available, relevant information was obtained through an interview with the well owner. The data base was transferred into a geographic information system to allow spatial analysis.

On the basis of depth and location, several wells were chosen for continuous measurement of water levels with pressure transducers. Either a $15-\mathrm{lb} / \mathrm{in}^{2}$ or a $50-\mathrm{lb} / \mathrm{in}^{2}$ pressure transducer was placed in the selected well. The pressure transducers were calibrated to manually measured water levels and set to record water-level data at a constant increment of time $(5,15$, or 30 minutes) or in response to a specified change in water level $(0.02 \mathrm{ft})$. Periodically the wells were measured manually to ensure the accuracy of the recorded water levels.

The discharge from AL-125 (Kendrick Woods Metro Park spring) was measured with a Parshall flume (Chow, 1959) and a pressure transducer. The transducer continuously measured gage height of water flowing through the 1 -in. throat of the flume. Gage height was translated to AL-125 discharge by use of the flume calibration formula

$$
Q=0.338 \times H^{1.55}
$$

where $Q$ is discharge in gallons per minute and $H$ is gage height in feet.

Measurements of gage height were made every 15 minutes or more frequently if gage height changed by $0.01 \mathrm{ft}$. The flume was visited periodically and recalibrated if necessary to ensure accuracy of gage-height measurements.

Water samples were collected in the field in accordance with USGS protocol described in Francy and others (1998). Temperature, dissolved oxygen, $\mathrm{pH}$, and specific conductance of water were measured prior to collection of the water samples; after a minimum of three borehole volumes of water were discharged from the well and when these same four measurements stabilized (within 5 percent for three consecutive measurements taken at an interval of at least 5 minutes), the water samples were collected. The samples were shipped to the USGS National Water Quality Laboratory, where they were analyzed by use of standard laboratory procedures (Fishman, 1993; Fishman and Friedman, 1989).

During May 1998, the USGS measured the specific capacity of 30 domestic wells and specific conductance and temperature of domestic well water using the following methods. A team of two USGS employees measured the static depth to water in the well after gaining permission from the well owner. If the depth to the pump setting was not known, either from a well log or an interview with the well owner, an attempt was made to measure the pump setting with a steel tape. A garden hose was attached to an outside spigot and directed to a ditch or other drainage away from the residence. The spigot was turned on, and discharge from the hose was measured with a stopwatch and a 5-gal bucket. At approximately 1-minute intervals the water level (drawdown) in the well was measured with an electric water-level tape. The field crew noted any pumping activity in the well when possible. The data were recorded, and a specific capacity was computed as discharge divided by maximum drawdown. Specific conductance and temperature of the water also were measured periodically during the test. 
Several downhole geophysical profiles (referred to as "logs") were taken in wells AL-64 and AL-85 to determine the hydraulic and geologic characteristics of the boreholes. The equipment used was Keck SR-3000 borehole logging system, which has digital recording capabilities and a calibrated wheel to accurately determine depth within the borehole. Standard USGS protocols (Keys and MacCary, 1971) were followed during the logging procedure.

Azimuthal electromagnetic (EM) conductivity surveys were done at two locations near wells AL-64 and AL-85. EM conductivity responds to electrical-conductivity variations in the subsurface resulting from variations in geology or water quality. These data were used to determine the anisotropy of underlying formations by recording directional values of electrical conductivity. A center stake was placed approximately $200 \mathrm{ft}$ north of well AL-85, and a Geonics EM-34 apparatus was rotated in 20-degree increments around the stake. EM data were measured at three coil spacings $(32.8,65.6$, and $131.2 \mathrm{ft})$, which generally correspond to increases in depth penetration. Two coil orientations (horizontal and vertical; "shallow" and "deep")[were L also used at each coil spacing. A second set of readings for the $65.6-\mathrm{ft}$ spacing was taken between wells $\mathrm{AL}-85$ ! and AL-64.

A variable-rate packer test was performed on well AL-64. An inflatable packer assembly was installed in AL-64 at a depth of approximately $180 \mathrm{ft}$, and a pump was placed below the packer. A constantrate discharge aquifer test was performed in well AL-85. During the aquifer tests, water was discharged from the pumping well into a pipe that terminated in a creek approximately $5 \mathrm{mi}$ from the site. For both tests, the discharge amount was monitored with a calibrated flowmeter. During the variable-rate packer test, selected water-quality measurements ( $\mathrm{pH}$, specific conductance, and dissolved oxygen) were made periodically with a hand-held water-quality monitor. For the constant-rate test, these water-quality measurements were made continuously with a flowthrough water-quality monitor.

During the variable-rate packer test in well AL-64, water levels above and below the packer were measured manually; water levels in seven surrounding wells were continuously monitored with pressure transducers set to record on regular time increments (15 minutes to 1 hour) or at a change of $0.05 \mathrm{ft}$ in water level in the well. Of these seven wells, three were domestic wells commonly used several times a day (AL-55, AL57, and AL-101), two were unused domestic wells
(AL-65 and AL-122), and two were observation wells at the proposed well field (AL-85 and AL-126). For the constant-rate aquifer test, these wells also were continuously monitored with pressure transducers set to record every 5 minutes. Two additional wells (AL-64 and AL-68) were added to the continuous recording network for the constant-rate aquifer test. Periodic manual measurements of water levels in recorder wells were made before, during, and after the test to ensure accuracy of the transducer measurements. Manual measurements of water levels also were made in 25 wells before, during, and after the variable-rate packer test and the constant-rate test.

Gage height at the flume (which is related to discharge from AL-125) was measured manually during the variable-rate packer test and continuously (15-minute intervals) by transducer for the constant-rate test. Gage height was periodically checked by field personnel.

During the period of aquifer testing, barometric pressure readings were made by use of a hand-held barometer. Hourly barometric pressure readings were later downloaded from $h t t p: / / w w w . n c d c . n o a a . g o v$ for Lima Allen County Airport, approximately $10 \mathrm{mi}$ from the proposed well field area. These data were used to correct for the effects of barometric pressure on water levels during the aquifer tests.

\section{BACKGROUND HYDROGEOLOGIC DATA}

During late April and May 1998, USGS personnel obtained permission to measure water levels in approximately 75 domestic and monitoring wells on and surrounding the proposed well field. Wells were completed either in the glacial aquifer (shallow sand units, typically at the base of the clay till) or in the underlying carbonate aquifer (completed at variable depths). The glacial sand units and carbonate aquifers in this area are confined aquifers under the glacial till, except near the Auglaize River, where the glacial sand unit can be locally unconfined. Information about the wells used in this study, including availability of well $\operatorname{logs}$, is listed in table 1 . Well locations are shown in figure 1 .

Information obtained from the well logs usually included depth to bedrock and some glacial stratigraphy. The bedrock surface is relatively flat, with elevations ranging from $771 \mathrm{ft}$ to $780 \mathrm{ft}$ in most of the study area. One well log in the western part of the study area shows a significantly lower bedrock surface, but this 
Table 1. Summary of general data for wells and AL-125 (Kendrick Woods Metro Park spring)

[ $\sim$, approximately; ft, feet; $\mu \mathrm{S} / \mathrm{cm}$, microsiemens per centimeter at 25 degrees Celsius; (gal $/ \mathrm{min}) / \mathrm{ft}$,

gallons per minute per foot of drawdown; -, data not available]

\begin{tabular}{|c|c|c|c|c|c|c|c|c|}
\hline $\begin{array}{l}\text { Well identifi- } \\
\text { cation num- } \\
\text { ber } \\
\text { cseetiz. }\end{array}$ & $\begin{array}{c}\text { State } \\
\text { well-jog } \\
\text { number }\end{array}$ & $\begin{array}{c}\text { Well } \\
\text { depth } \\
(\mathrm{ft})\end{array}$ & $\begin{array}{c}\text { Type of } \\
\text { well }\end{array}$ & $\begin{array}{c}\text { Pump-intake } \\
\text { depth } \\
\text { (ft) } \\
t\end{array}$ & $\begin{array}{c}\text { Water } \\
\text { level } \\
\text { from } \\
\text { state log } \\
\text { (ft) }\end{array}$ & $\begin{array}{c}\text { Water } \\
\text { level, } \\
\text { USGS } \\
\text { April/May } \\
1998 \\
\text { (ft) }\end{array}$ & $\begin{array}{c}\text { Specific } \\
\text { conductance } \\
(\mu \mathrm{S} / \mathrm{cm})\end{array}$ & $\begin{array}{c}\text { Specific } \\
\text { capacity } \\
{[(g a l / m i n) / f t]}\end{array}$ \\
\hline AL-50 & 852565 & 120 & Domestic & $110 \vdots$ & 40 & 21.59 & 1,225 & - \\
\hline AL-52 & 758001 & 171 & Domestic & $\sim 125$ & 34 & 16.11 & - & - \\
\hline AL-53 & 745797 & 100 & Domestic & 95 & 25 & 27.37 & - & - \\
\hline AL-54 & 665651 & 27 & Domestic & 24 & 12 & 7.97 & 585 & 2.62 \\
\hline AL-55 & 651475 & 188 & Domestic & 90 & 22 & 24.10 & 1,152 & 14.1 \\
\hline AL-56 & 604447 & 124 & Domestic & 100 & 20 & 18.07 & 850 & 6.1ิ9 \\
\hline AL-57 & 516666 & 113 & Domestic & 60 & 24 & 19.85 & 1,229 & 2.58 \\
\hline AL-58 & 310049 & 65 & Domestic & $\sim 45$ & 22 & 18.53 & - & - \\
\hline AL-59 & 818025 & 32 & Domestic & 29 & 21 & 20.51 & - & - \\
\hline$A L-60$ & 813021 & 34 & Domestic & $\sim 30$ & 14 & 17.93 & - & - \\
\hline AL-61 & 813008 & 34 & Domestic & - & 14 & 17.07 & - & - \\
\hline AL-62 & 631869 & 35 & Domestic & $\sim 30$ & 9 & 19.03 & - & - \\
\hline$A L-63$ & 604423 & 40.9 & Domestic & $\sim 30$ & 10 & 16.13 & 1,437 & - \\
\hline AL-64 & 822344 & 300 & Monitoring & - & - & 15.67 & - & - \\
\hline AL-65 & 625549 & 122 & Domestic & - & - & 17.02 & - & - \\
\hline AL-66 & 813003 & 82 & Domestic & 82 & 16 & 11.30 & 1,410 & 6.25 \\
\hline AL-67 & - & 31 & Domestic & pump in house & - & 13.24 & - & - \\
\hline AL-68 & - & 100 & Agricultural & $\sim 80$ & - & 54.30 & 1,118 & - \\
\hline AL-69 & - & 50 & Domestic & $\sim 40$ & - & 14.82 & - & - \\
\hline AL-70 & - & 130 & Domestic & $\sim 100$ & - & 23.70 & 1,040 & .19 \\
\hline AL-71 & 604423 & 38 & Domestic & - & 10 & 18.83 & - & \\
\hline AL-72 & - & 45 & Domestic & $\sim 38$ & - & 16.46 & 1,520 & .38 \\
\hline AL-73 & - & 62 & Domestic & $\sim 50$ & - & 20.05 & 1,418 & .17 \\
\hline AL-74 & - & 77 & Domestic & $\sim 60$ & - & 15.83 & 1,390 & .28 \\
\hline AL-75 & - & - & Domestic & - & - & 19.04 & - & - \\
\hline AL-76 & 604416 & 119 & Domestic & $\sim 28$ & - & 19.62 & 1,590 & 11.1 \\
\hline AL-77 & - & 95 & Domestic & - & - & 15.51 & 1,451 & 1.25 \\
\hline AL-78 & - & 83 & Domestic & $\sim 70$ & - & 16.77 & 1,430 & .62 \\
\hline AL-79 & - & 67 & Domestic & 50 & - & 18.32 & 1,483 & 2.66 \\
\hline AL-80 & - & 64 & Domestic & $\sim 55$ & - & 16.56 & 1,469 & 1.03 \\
\hline AL-81 & 852563 & 142 & Domestic & $\sim 120$ & 40 & 38.54 & 1,230 & .36 \\
\hline AL-82 & - & 78 & Domestic & 70 & - & 21.51 & 1,850 & .93 \\
\hline AL-83 & - & 45 & Domestic & 40 & - & 20.22 & 1,309 & .47 \\
\hline AL-84 & 769294 & 148 & Domestic & 75 & 32 & 20.71 & 1,217 & .29 \\
\hline AL-85 & 822345 & 315 & Monitoring & - & - & 20.61 & - & - \\
\hline AL-86 & 486600 & 74 & Domestic & 70 & 30 & 19.44 & - & - \\
\hline AL-87 & - & $\sim 30$ & Domestic & $\sim 25$ & - & 13.80 & - & - \\
\hline AL-88 & - & $\sim 30$ & Domestic & $\sim 25$ & - & 15.27 & 1,312 & - \\
\hline AL-89 & - & 30 & Domestic & $\sim 25$ & - & 17.00 & 1,405 & - \\
\hline AL-90 & $\cdot$ & 45 & Domestic & 40 & - & 20.33 & 1,500 & 17.5 \\
\hline AL-91 & - & 55 & Domestic & 45 & - & 13.11 & 1,940 & 2.62 \\
\hline AL-92 & - & 90 & Domestic & 60 & - & 17.27 & 1,443 & 0.27 \\
\hline AL-93 & - & 34 & Domestic & & - & 12.83 & 1,355 & 8.13 \\
\hline AL-94 & - & 32 & Domestic & 29 & - & 18.41 & 1,084 & 5.83 \\
\hline AL-95 & - & - & Domestic & - & - & 18.91 & 1,166 & .17 \\
\hline
\end{tabular}


Table 1. Summary of general data for wells and AL-125 (Kendrick Woods Metro Park spring) - Continued $[\sim$, approximately; $\mathrm{ft}$, feet; $\mu \mathrm{S} / \mathrm{cm}$, microsiemens per centimeter at 25 degrees Celsius; (gal/min)/ft,

gallons per minute per foot of drawdown; -, data not available]

\begin{tabular}{|c|c|c|c|c|c|c|c|c|}
\hline $\begin{array}{l}\text { Well identifi- } \\
\text { cation num- } \\
\text { ber } \\
(\end{array}$ & $\begin{array}{c}\text { State } \\
\text { well- log } \\
\text { number }\end{array}$ & $\begin{array}{c}\text { Well } \\
\text { depth } \\
\text { (ft) }\end{array}$ & $\begin{array}{c}\text { Type of } \\
\text { well }\end{array}$ & $\begin{array}{l}\text { Pump-intake } \\
\text { depth } \\
\text { (ft) }\end{array}$ & $\begin{array}{c}\text { Water } \\
\text { ievel } \\
\text { from } \\
\text { state log } \\
\text { (ft) }\end{array}$ & $\begin{array}{c}\text { Water } \\
\text { level, } \\
\text { USGS } \\
\text { April/May } \\
1998 \\
\text { (ft) }\end{array}$ & $\begin{array}{c}\text { Specific } \\
\text { conductance } \\
(\mu \mathrm{S} / \mathrm{cm})\end{array}$ & $\begin{array}{c}\text { Specific } \\
\text { capacity } \\
{[(g a l / m / n) / f t]}\end{array}$ \\
\hline$\overline{A L-96}$ & 604404 & 95 & Domestic & & 30 & 15.48 & - & - \\
\hline AL-97 & - & 30 & Domestic & 25 & - & 11.28 & 1,670 & 1.08 \\
\hline AL-98 & - & -52 & Domestic & - & - & 14.78 & - & - \\
\hline AL-99 & - & 215 & Domestic & 140 & - & 23.3 & 1,320 & .09 \\
\hline AL-100 & - & 69 & Domestic & pump in house & - & 19.42 & 1,235 & - \\
\hline AL-101 & 677295 & 36 & Domestic & 29 & 12 & 15.30 & 1,414 & 3.33 \\
\hline AL-102 & - & 30 & Domestic & $\sim 25$ & - & 14.40 & - & - \\
\hline AL-103 & - & 112 & Domestic & - & - & 17.80 & - & - \\
\hline AL-104 & - & $\sim 133$ & Domestic & $\sim 100$ & - & 20.90 & - & - \\
\hline AL-105 & - & 170 & Domestic & - & - & 25.00 & - & - \\
\hline AL-106 & - & $\sim 160$ & Domestic & hand pump & - & 20.80 & - & - \\
\hline AL-107 & 813010 & 29 & Domestic & - & 11 & 10.50 & - & - \\
\hline AL-108 & - & - & Domestic & - & - & 30.20 & - & - \\
\hline AL-109 & 759218 & 142 & Domestic & - & 25 & 23.20 & - & .36 \\
\hline AL-110 & 677255 & 28 & Domestic & - & 12 & 16.30 & - & 4.50 \\
\hline AL-111 & 745789 & 29 & Domestic & - & 12 & 11.30 & - & 3.33 \\
\hline AL-112 & - & 95 & Domestic & $\sim 80$ & - & 18.00 & - & - \\
\hline AL-113 & - & 66 & Domestic & $\sim 60$ & - & 22.10 & - & - \\
\hline AL-114 & - & - & Domestic & - & - & 8.41 & - & - \\
\hline AL-115 & - & - & Domestic & - & - & 21.60 & - & - \\
\hline AL-116 & - & 100 & Domestic & - & - & 27.70 & - & - \\
\hline AL-117 & -- & 48 & Domestic & - & - & 22.40 & - & - \\
\hline AL-118 & 737481 & 40 & Domestic & $\sim 30$ & 16 & 15.31 & - & 3.33 \\
\hline AL-119 & - & 44 & Domestic & 28 & - & 18.75 & - & - \\
\hline AL-120 & - & 44 & Domestic & 32 & - & 20.21 & - & - \\
\hline AL-121 & - & 33 & Domestic & $\sim 28$ & - & 12.31 & - & - \\
\hline AL-122 & - & 32 & Domestic & - & - & 19.94 & - & - \\
\hline AL-123 & - & $\sim 30$ & Domestic & - & - & 14.19 & - & - \\
\hline AL-124 & - & 180 & Domestic & - & - & - & - & - \\
\hline AL-125 & - & - & Spring & - & - & - & - & - \\
\hline AL-126 & - & -30 & Monitoring & 25 & - & - & - & - \\
\hline
\end{tabular}


elevation is not supported by previous bedrock topography studies in the area (Kostelnick, 1981).

Measured water levels in the carbonate aquifer indicate a near-zero horizontal hydraulic gradient in the study area. Near the Auglaize River, water levels in shallow and deep carbonate-aquifer wells indicate an upward vertical hydraulic gradient toward the river. Water-level elevations from two adjacent wells in the carbonate aquifer near the proposed well field, AL-50 (depth of well, $120 \mathrm{ft}$ ) and AL-100 (depth of well, $69 \mathrm{ft}$ ), indicate a downward vertical hydraulic gradient. Water levels in the shallow unconsolidated sand units compared with water levels in nearby carbonate-aquifer wells also indicate a downward vertical hydraulic gradient to the carbonate aquifer.

Specific capacity of 30 domestic wells was measured to determine whether any spatial trends or trends with depth could be detected. A spatial trend in specific capacity may indicate anisotropy in transmissivity of an aquifer, and a trend with depth can indicate vertical variability in transmissivity. A plot of specific capacity as a function of well depth (fig. 2) indicates no trend with depth of well completion. Also, no spatial trends were indicated by plotting the data on a map.

Borehole geophysical logs taken in wells AL-85 and AL-64 to identify water-bearing fractures and stratigraphy are similar. The geophysical logs and the interpreted hydrogeologic section for well AL-85 are shown in figure 3 . A caliper log shows the size of the borehole; caliper readings larger than the drilled diameter indicate places where the borehole intersects fractures in the bedrock. A temperature log shows changes in temperature in a borehole that indicate water movement into or out of the borehole. Natural gamma logs generally show increases in gamma ray emissions at depths where clay or shale in the formation increase. Electrical resistivity logs generally show decreases in resistivity with increased amounts of clay/shale. The geophysical logs and interpreted stratigraphic section for wells AL-85 (fig. 3) and AL-64 indicate till to a depth of approximately $35 \mathrm{ft}$ underlain by limestone or dolomite. The temperature logs indicate an absence of water-bearing fractures in the carbonate aquifer to a depth of approximately 190 feet. Water-bearing fractures are present from $190 \mathrm{ft}$ to $260 \mathrm{ft}$; this interval probably corresponds to the Guelph Dolomite (Janssens, 1977).

The results of the azimuthal EM conductivity surveys are presented as a series of polar plots designed to reveal dominant fracture orientation with depth (fig. 4). Since fracture orientation may be indicative of aquifer anisotropy, the polar plots can be examined to
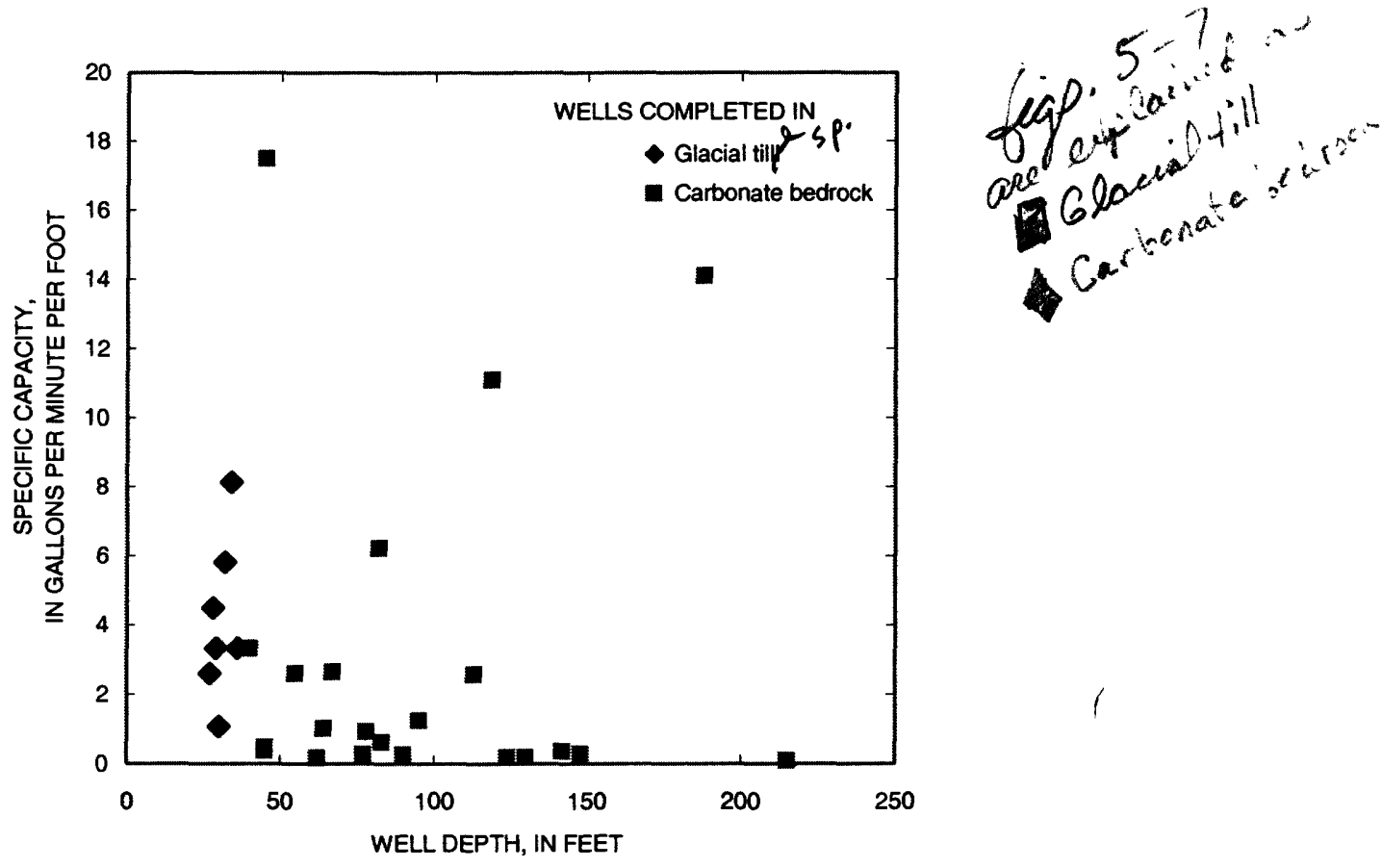

Figure 2. Specific capacity as a function of well depth, western Allen County, Ohio. 


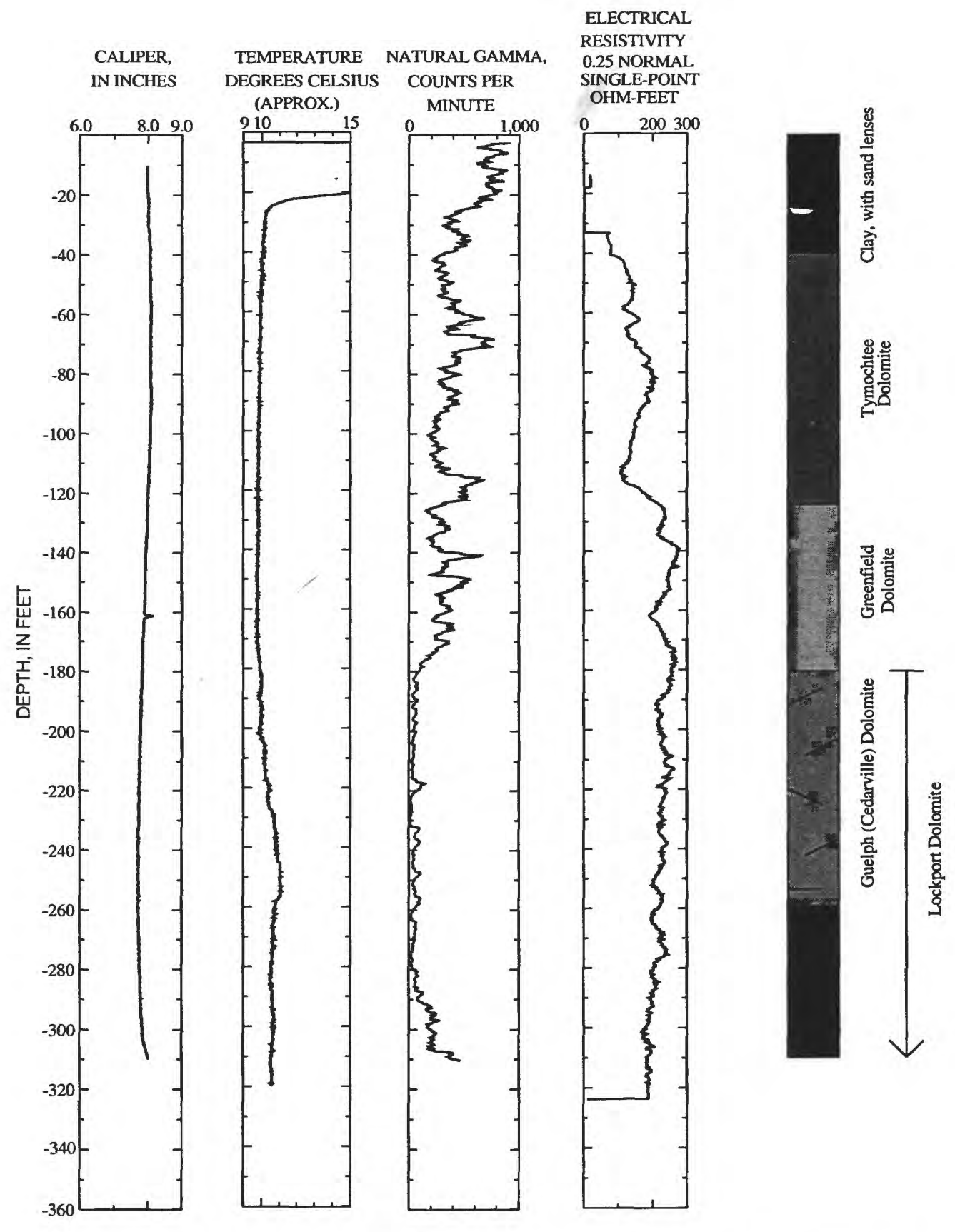

Figure 3. Borehole geophysical logs and interpreted stratigraphic section of well AL-85, western Allen County, Ohio. 


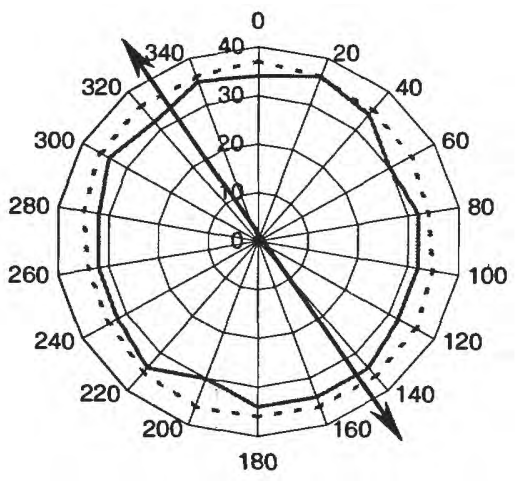

32.8-FOOT COIL SPACING

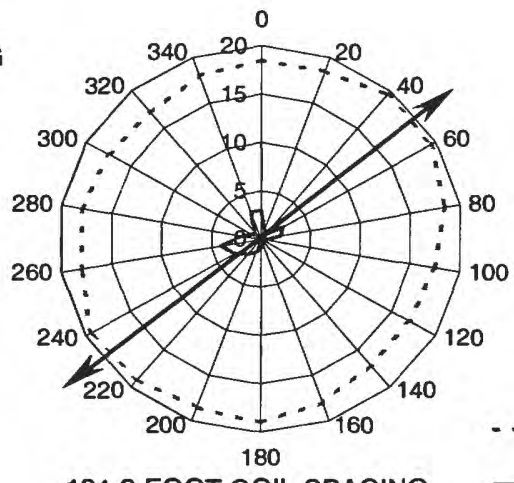

131.2-FOOT COIL SPACING

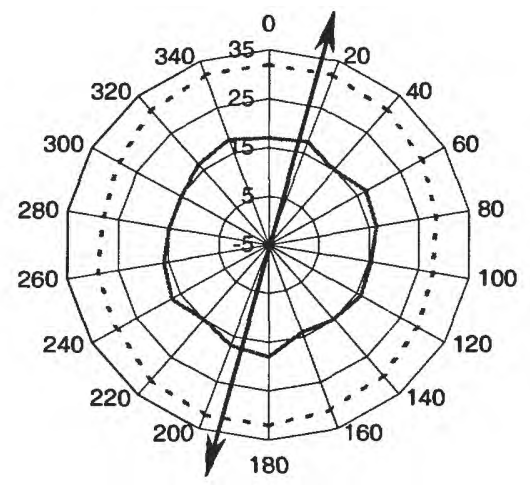

65.6-FOOT COIL SPACING

\section{EXPLANATION}

HORIZONTAL DIPOLE

VERTICAL DIPOLE

Figure 4. Polar plots of azimuthal electromagnetic surveys done $200 \mathrm{ft}$ north of well AL-85, western Allen County, Ohio, for three coil separations. Internal scale is millisiemens per meter, and outer scale is degrees (angle of transmitter from north). Arrows indicate possible trends in data.

determine possible preferred drawdown in wells. The electrical-conductivity scale is plotted on the radial axis as a function of compass direction and is interpreted as changes in electrical conductivity with direction. Successively larger coil spacings result in greater depths of penetration. Results from the 32.8-ft-spacing data indicate a very slight northwest-southeast trend in EM conductivity, corresponding to the orientation of some lineations at the surface inferred from aerial photographs. The deeper penetration of the 65.6- and 131.2-ft-spacing data indicate that the trend of fracture orientation changes with depth to the northeast-southwest, corresponding to a few possible lineations with a general northeast-southwest trend in the aerial photo- graphs. These directional trends are minor and may be obscured by the signal noise, which was not quantified in the surveys; previous work with azimuthal EM conductivity surveys indicate that signal noise may be a large interference and should be quantified for reliable interpretation (Slater and others, 1998).

\section{WATER QUALITY}

Results of water-quality analyses on samples from 10 wells and AL-125 (Kendrick Woods Metro Park spring) are given in table 2. Interviews with domestic well owners indicated an increase in water 


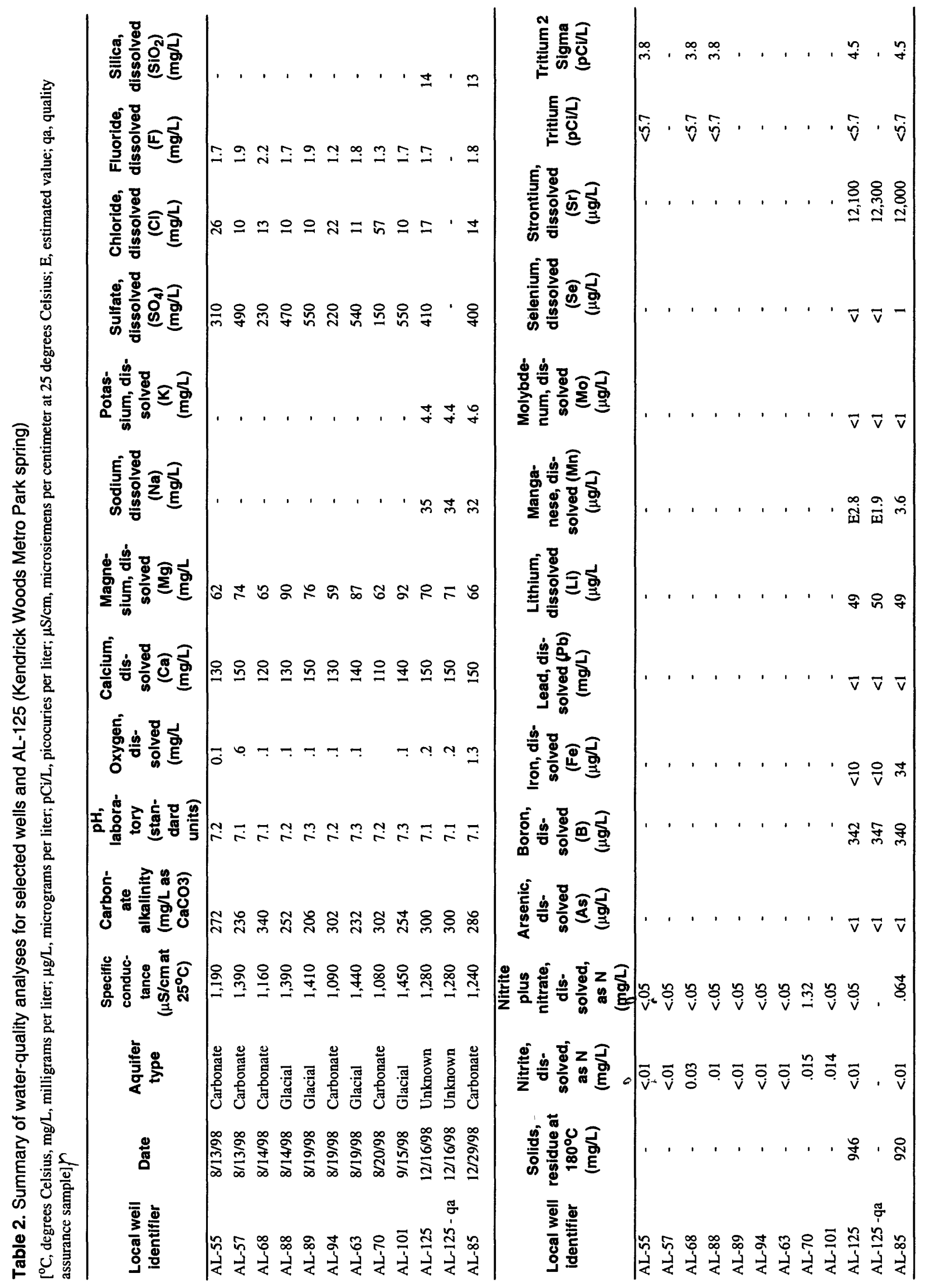


odor and taste problems with well depth. By plotting selected water-quality measurements in relation to well depth, aspects of the vertical variability in water quality can be determined (figs. 5 through 7).

Variation in specific conductance with well depth and geologic unit is shown in figure 5. Specific conductance provides an indication of ionic concentration in a water and is related to dissolved-solids concentration. Within the study area, the specific conductance of glacial-aquifer water generally is higher and less variable than the specific conductance of carbonate-aquifer water.

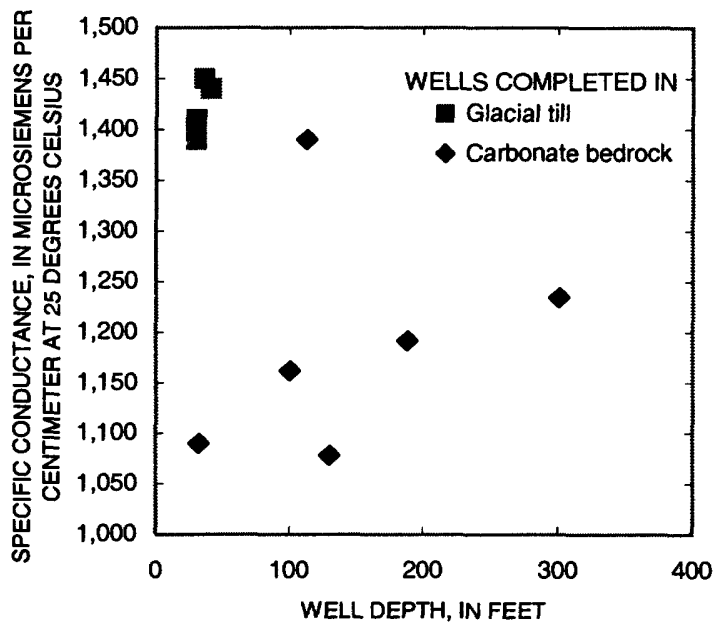

Figure 5. Relation of specific conductance to well depth, western Allen county, Ohio. Specific conductance of the Kendrick Woods spring is 1275 microsiemens per centimeter.

Carbonate alkalinity with respect to well depth is shown in figure 6. Glacial-aquifer water in the study area generally has lower carbonate alkalinity than the carbonate-aquifer water. A slight decrease in carbonate alkalinity with depth in the carbonate aquifer corresponds to an increase of carbonate or bicarbonate species in the ground water with depth. Also, the variability of alkalinity for water from the glacial aquifer (less than $40 \mathrm{ft}$ well depth) tends to be less than that of water derived from the carbonate aquifer.

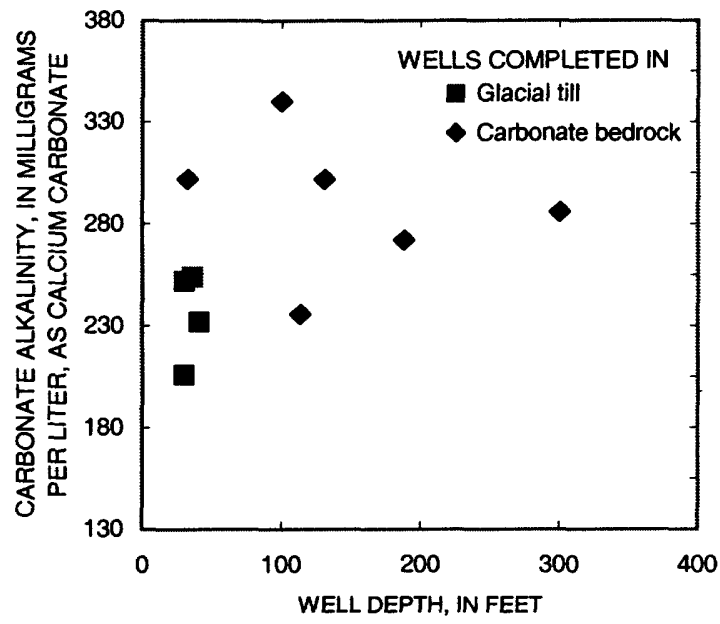

Figure 6. Relation of carbonate alkalinity to well depth, western Allen County, Ohio. Alkalinity of the Kendrick Woods spring is $\mathbf{3 0 0}$ milligrams per liter as calcium carbonate.
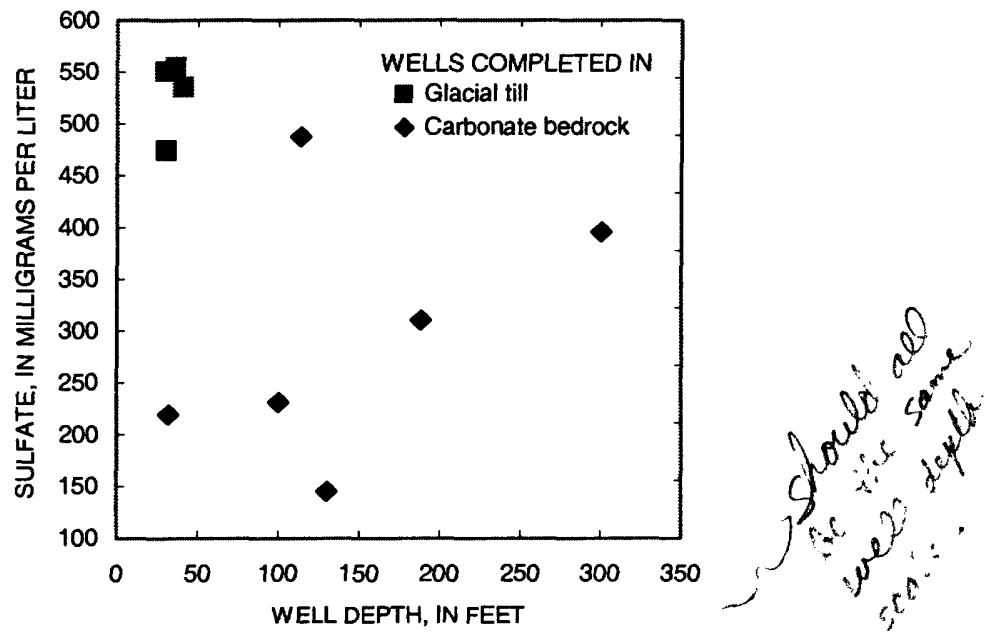

Figure 7. Relation of sulfate concentration to well depth, western Allen County, Ohio. Sulfate concentration of the Kendrick Woods spring is $\mathbf{4 1 0}$ milligrams per liter.

Sulfate concentration with respect to well depth is shown in figure 7. Glacial-aquifer water in the study area is higher in sulfate than carbonate-aquifer water. Variability in sulfate concentration within the carbonate aquifer is large. The reduction of sulfate to form odor-producing sulfide may be highly variable spatially and with depth. This finding does not support domestic 
well owners' observations of water having a worse odor with increasing depth of well completion. Most people can detect the rotten-egg odor of hydrogen sulfide at concentrations of a few tenths of a milligram per liter (Hem, 1989).

Tritium concentrations were less than $5.7 \mathrm{pCi} / \mathrm{L}$ $(<2$ TU) in water from four wells sampled, including two glacial-aquifer wells $(5.7 \mathrm{pCi} / \mathrm{L}$ is the detection limit of the laboratory method). Water from AL-125 (Kendrick Woods Metro Park spring) also had a tritium concentration less than $5.7 \mathrm{pCi} / \mathrm{L}(<2 \mathrm{TU})$. The relatively low concentration of tritium indicates that water from these sources probably was recharged to the aquifers before the mid-1950's. Concentrations of tritium that are low or non-detectable indicate water recharged before precipitation was enriched with tritium by the above-ground testing of atomic bombs in the 1950's and 1960's (Carter and Moghissi, 1977).

\section{AQUIFER CHARACTERISTICS}

Aquifer tests were done at wells AL-64 and AL85 to determine aquifer characteristics in and around the proposed well field. These tests also were designed to determine response of water levels in surrounding wells and flow rates at AL-125 under different pumping scenarios.

\section{Results of Variable-Rate Packer Test}

A variable-rate packer test was done at well AL64 in October 1998 to determine how pumping from a lower part of the carbonate aquifer affects local ground-water levels, including those in the upper part of the carbonate aquifer, and to observe effects on flow from AL-125 (Kendrick Woods Metro Park spring). The packer was placed to isolate the lower, more fractured part of the carbonate aquifer (Guelph Dolomite, fig. 3) from the upper carbonate aquifer, which is used more heavily by local water users. Difficulties with the pump and maintaining water flow during the test rendered the collected water-level data unsuitable for analysis of aquifer properties, but visual comparisons of the data can be made. Water levels for wells AL-64 (above and below the packer), AL-85, AL-65, and AL-125

(Kendrick Woods Metro Park spring) are shown in figure 8. Water levels from AL-85 and below the packer in AL-64 indicate that this part of the aquifer is highly connected areally. Water levels above the packer in
AL-64 show a muted response to pumping, indicating a diminished hydraulic connection between the upper and lower carbonate aquifer. The response of flow (gage height) in the flume (AL-125) indicates that the source of water flowing from AL-125 likely is the carbonate aquifer. Data recorded during pumping and subsequent recovery periods indicate a downward vertical gradient between the upper and lower carbonate aquifer, as seen by water levels above and below the packer in AL-64.

Figure 9 shows the response of water levels in glacial-aquifer wells (AL-101, AL-122, and AL-126) and a shallow carbonate-aquifer well (AL-65) near AL64 (fig. 1). The water levels from above the packer in well AL-64 are shown for comparison. The glacialaquifer wells show no apparent response to the pumping from the lower part of the carbonate aquifer. The response of water levels in well AL-65 is similar to that of water levels in AL-64 above the packer, indicating that the upper and lower carbonate aquifer are hydraulically connected areally. Water levels measured by hand in the 25 domestic wells surrounding the pumped well did not indicate any measurable effects of pumping.

\section{Results of Constant-Rate Aquifer Test}

A constant-rate aquifer test was done at well AL85 in December 1998 to determine the aquifer properties transmissivity $(T)$ and storage coefficient (S), to determine how pumping affects local ground-water levels, and to observe pumping effects on flow from AL-125 (Kendrick Woods Metro Park spring). The day before the constant-rate test, a step-pumping test was done at well $\mathrm{AL}-85$ to determine the pumping rate for the constant-rate test. From the response of flow at AL125 and water levels in the pumping well (AL-85), $70 \mathrm{gal} / \mathrm{min}$ was determined to be a reasonable flow rate for the constant-rate test. At 10:45 a.m. local time on December 15, 1998, the constant-rate test began. After 12.5 hours, the test was stopped because of decreased flow from AL-125. The average pumping rate for the well was about $70.5 \mathrm{gal} / \mathrm{min}$ and varied no more than $2 \mathrm{gal} / \mathrm{min}$ during the course of the test. The depth to water in AL85 after 12.5 hours of pumping was approximately $120 \mathrm{ft}$ below land surface. Figure 10 shows the water-level response to pumping at AL-64 for 2 days before, during, and after the constant-rate test. The figure also shows continuous barometric-pressure measurements for the same time period. The response of water levels in the 


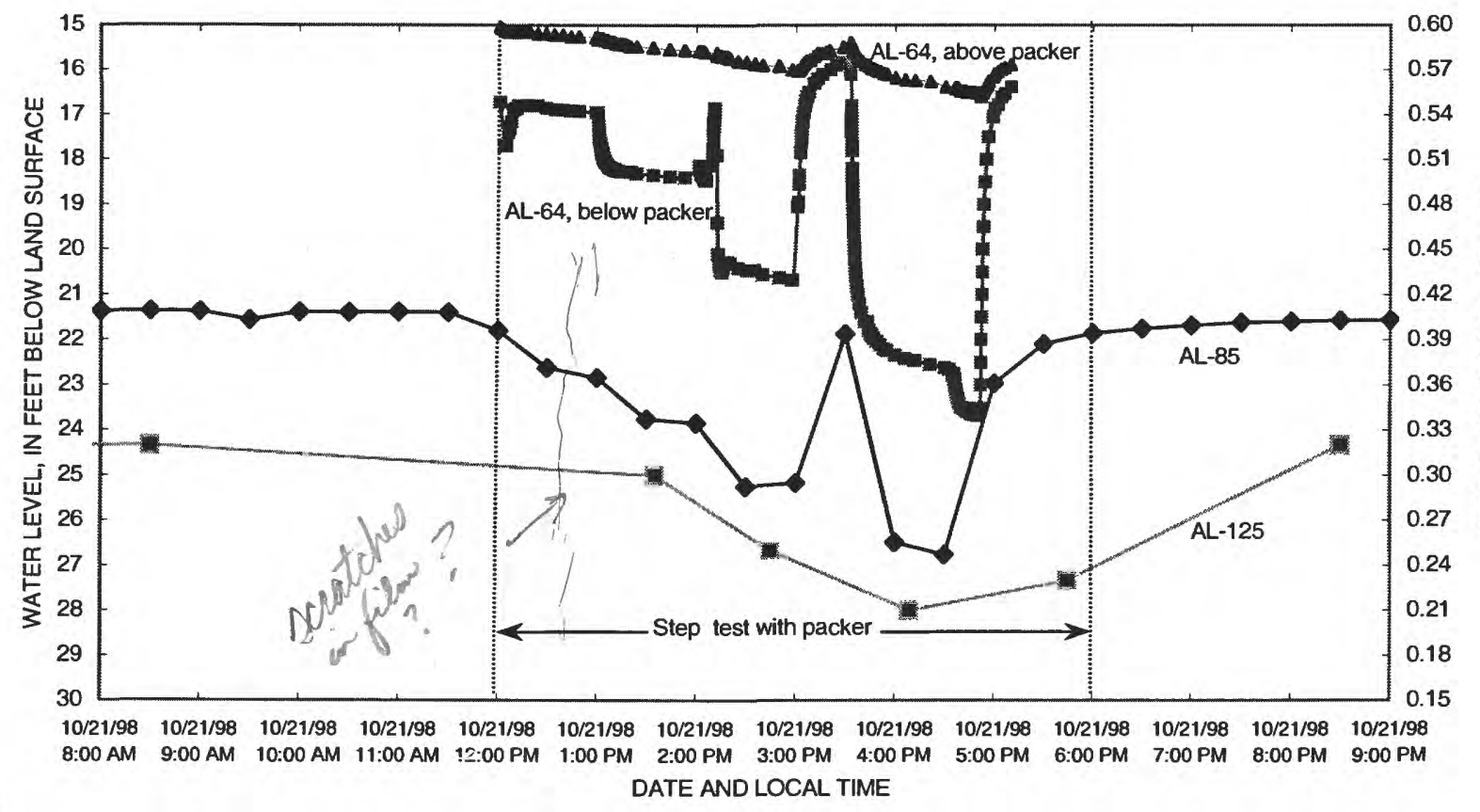

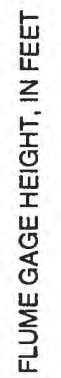

Figure 8. Water levels for wells AL-64, AL-85, and AL-125 (Kendrick Woods spring) during a variablerate packer test on AL-64, western Allen County, Ohio. An inflatable packer was placed at approximately 180 feet depth in AL-64, and a pump was placed below the packer.

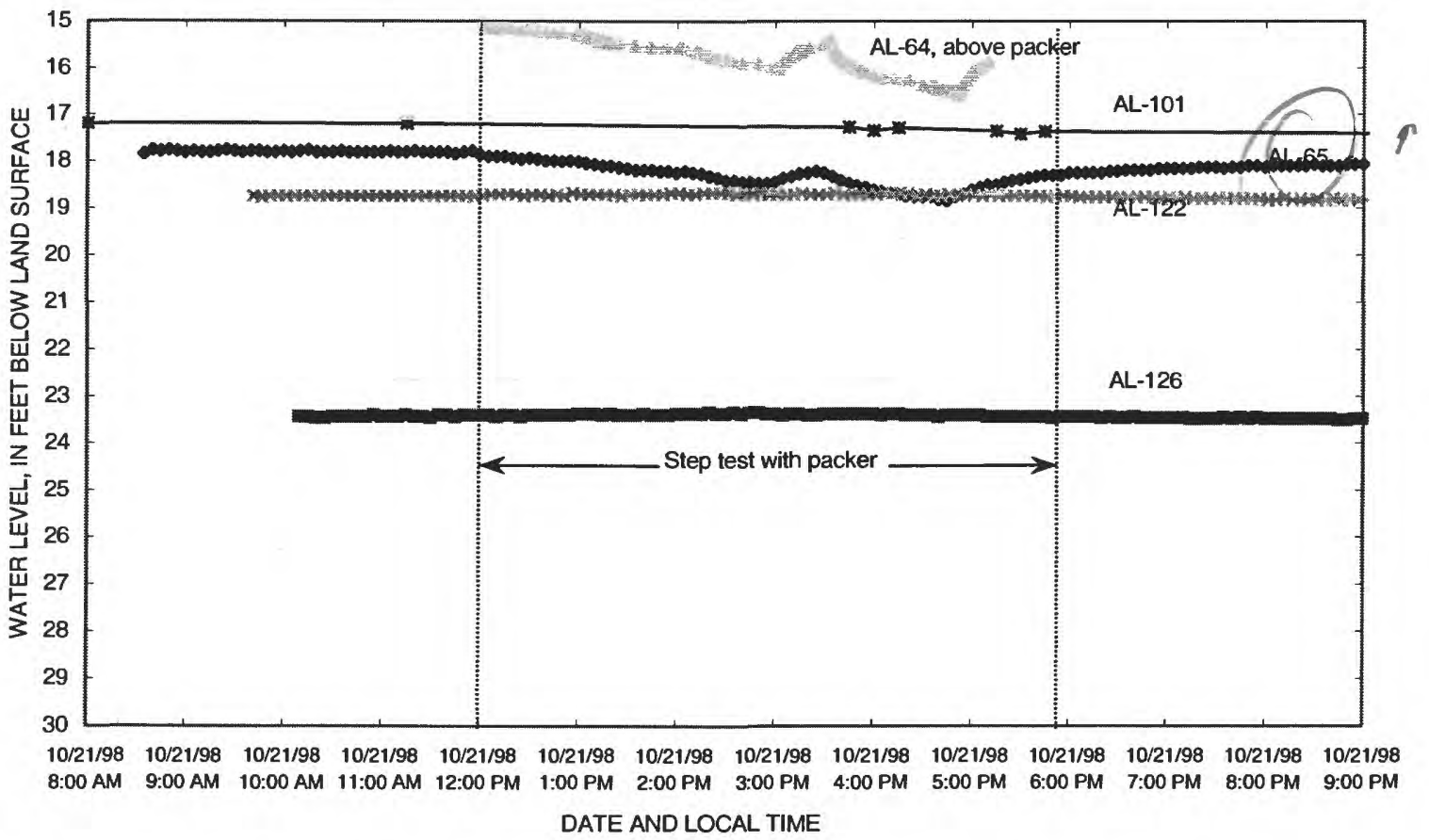

Figure 9. Water levels for wells completed in the glacial aquifer (AL-122, AL-126) and wells completed in the upper carbonate aquifer (AL-65, AL-64 above packer, AL-101), during a variable-rate packer test in well AL-64, western Allen County, Ohio. An inflatable packer was placed at approximately 180 feet depth in well Al-64, and a pump was placed below the packer. 


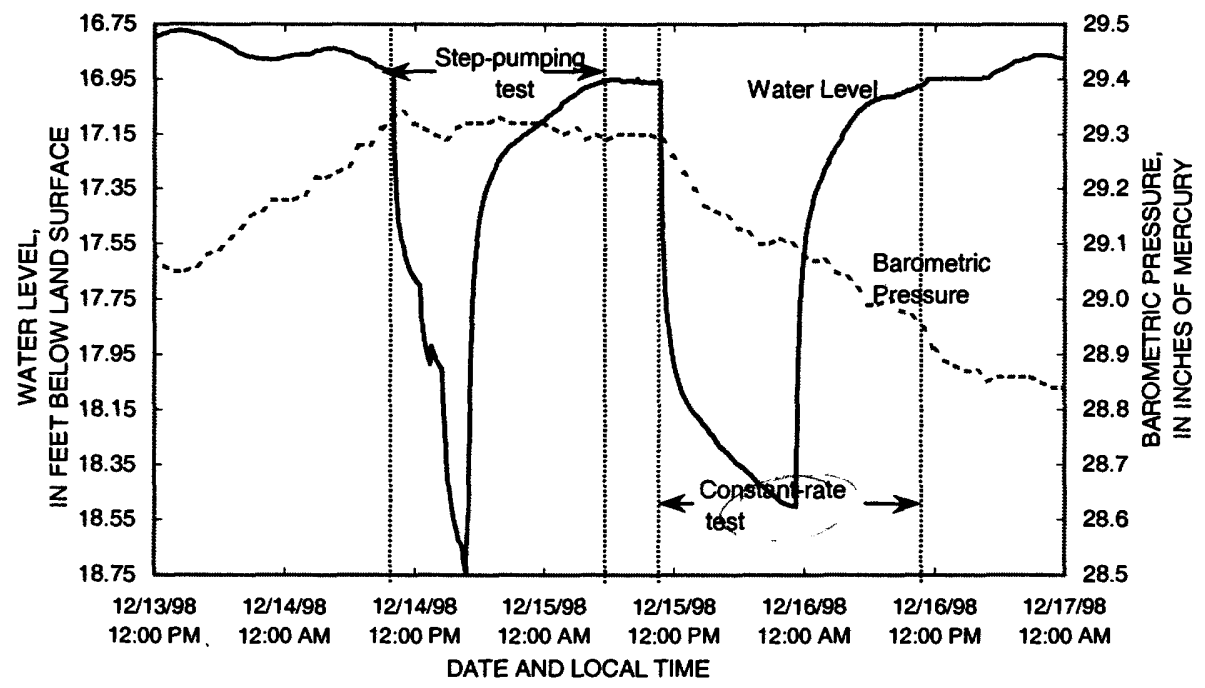

Figure 10. Water levels for well AL-64 and barometric pressure during the step-pumping and constant-rate tests at well AL-85, western Allen County, Ohio.

well to barometric pressure before and after the test indicate that barometric pressure may be contributing to some of the change in water levels. A plot of barometric pressure against water levels for a period of no pumping (fig. 11) indicates a barometric efficiency of approximately 39 percent (the slope of the best-fit line; for example, a barometric pressure change of 1 in. of mercury results in a water-level change of $0.39 \mathrm{ft}$ ) and demonstrates the need for barometric corrections before analysis of the aquifer-test data.The time-drawdown data for AL-64, after correction for barometricpressure effects, are shown in figure 12. The data were analyzed by means of Theis-type-curve matching methods (Theis, 1935) to obtain values for T and S. On the basis of water level response of AL-64 to pumping at well AL-85, values of $\mathrm{T}$ and $\mathrm{S}$ are approximately $28,500(\mathrm{gal} / \mathrm{d}) / \mathrm{ft}$ and $3.03 \times 10^{-5}$, respectively.

Well AL-65, a hand-pump well at Kendrick Woods Metro Park, was unused at the time of the aquifer tests and was equipped with a pressure transducer. The barometric-pressure correlation with water levels in AL-65 during a nonpumping period shows a barometric efficiency of 41 percent (fig. 13). The timedrawdown data for the time period of the constant-rate test is shown in figure 14, along with the Theis type curve, which indicates a $\mathrm{T}$ and $\mathrm{S}$ of approximately $30,700(\mathrm{gal} / \mathrm{d}) / \mathrm{ft}$ and $4.7 \times 10^{-4}$, respectively. By use of the straight-line method of aquifer-test analysis
(Cooper and Jacob, 1946), the late-time data (after 200 minutes of pumping) are matched for the same $T$ and $S$ (fig. 15).

Other observation wells instrumented with pressure transducers included two wells completed in basal sand units within the glacial till (AL-122 and AL-126). Water levels measured in these wells, along with the barometric pressure for several days before and after the constant-rate aquifer test are shown in figure 16. No obvious effects due to pumping are evident; barometric-pressure effects dominate the water-level response. The barometric efficiencies of wells AL-122 and AL126 are approximately 37 percent and 64 percent, respectively.

The remainder of wells with continuous waterlevel recorders were periodically used domestic wells. AL-101, a well completed in a sand layer probably at the base of the glacial till showed indications of being affected by the pumping at well AL-85 (fig. 17). To assess the response of well AL-101 to pumping in the test well (AL-85), drawdown from well use was removed. Additionally, water levels in AL-101 were corrected for barometric-pressure effects. The results of the corrections are shown in figure 18. An attempt was made to use the drawdown at AL-101 associated with the constant-rate test for the analysis of aquifer characteristics, and the resulting time-drawdown curve 


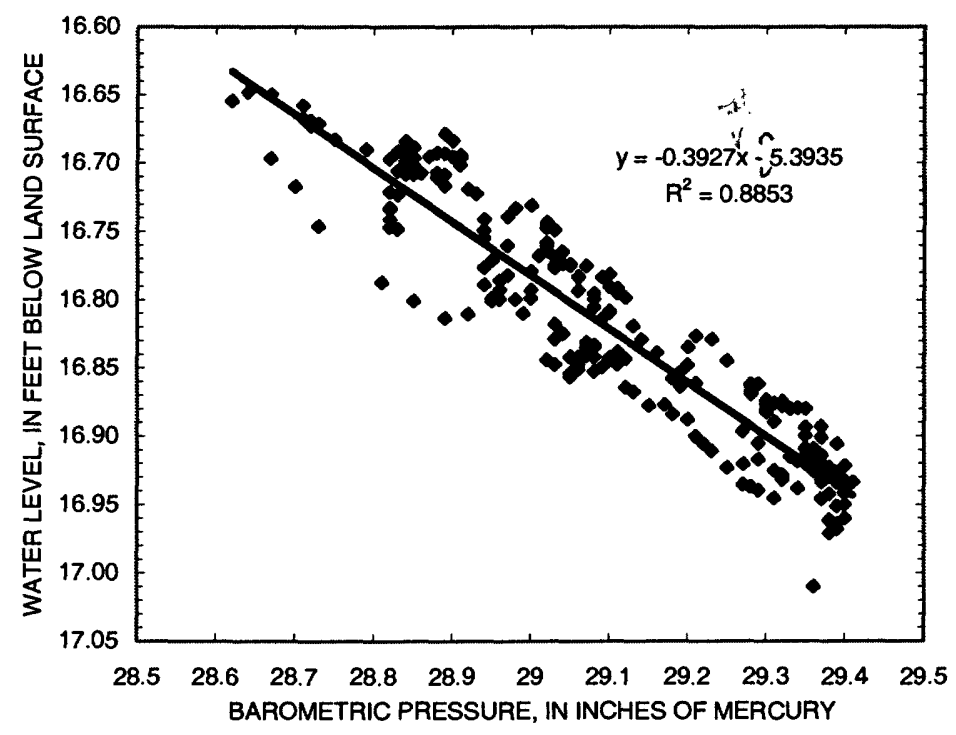

Figure 11. Barometric pressure as a function of water level for well AL-64, western Allen County, Ohio, for a period of no pumping.

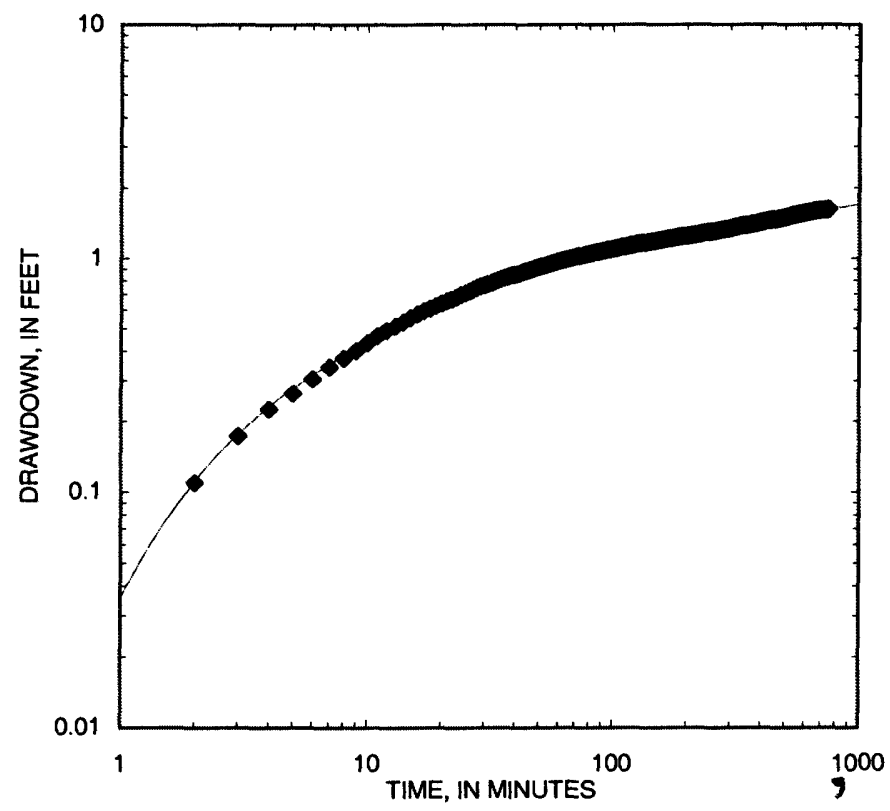

Figure 12. Time-drawdown data for well AL-64 (12/15/98), western Allen County, Ohio. Theis type curve is shown as a line on the graph and corresponds to a transmissivityof 28,500 gallons per day per foot and a storage coefficient of $3.03 \times 10^{-5}$. 


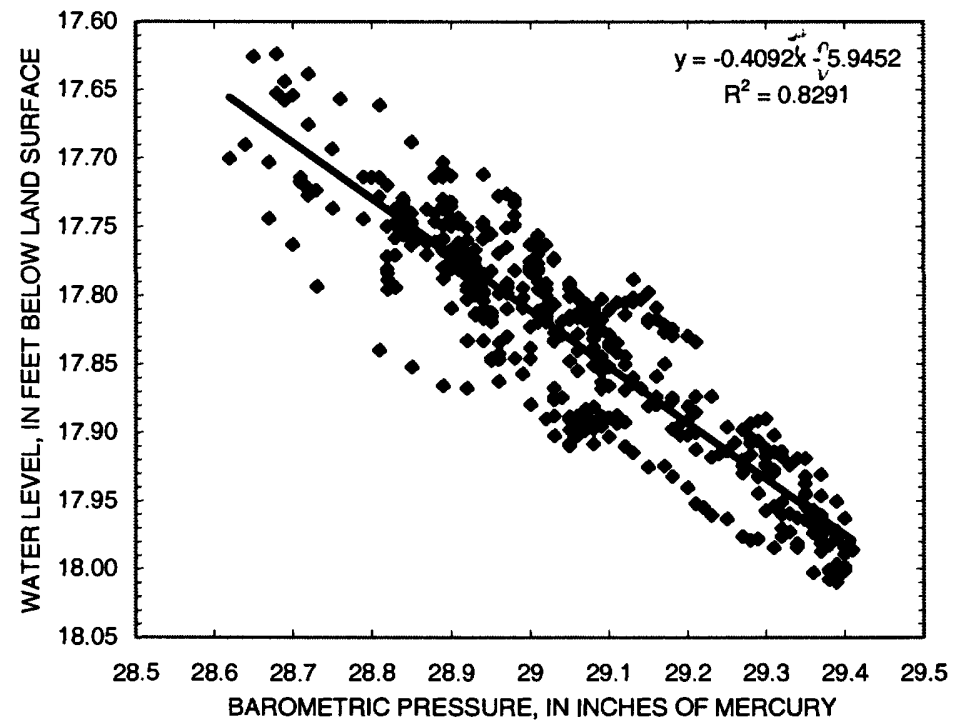

Figure 13. Barometric pressure as a function of water level for well AL-65, western Allen County, Ohio, for a period of no pumping.

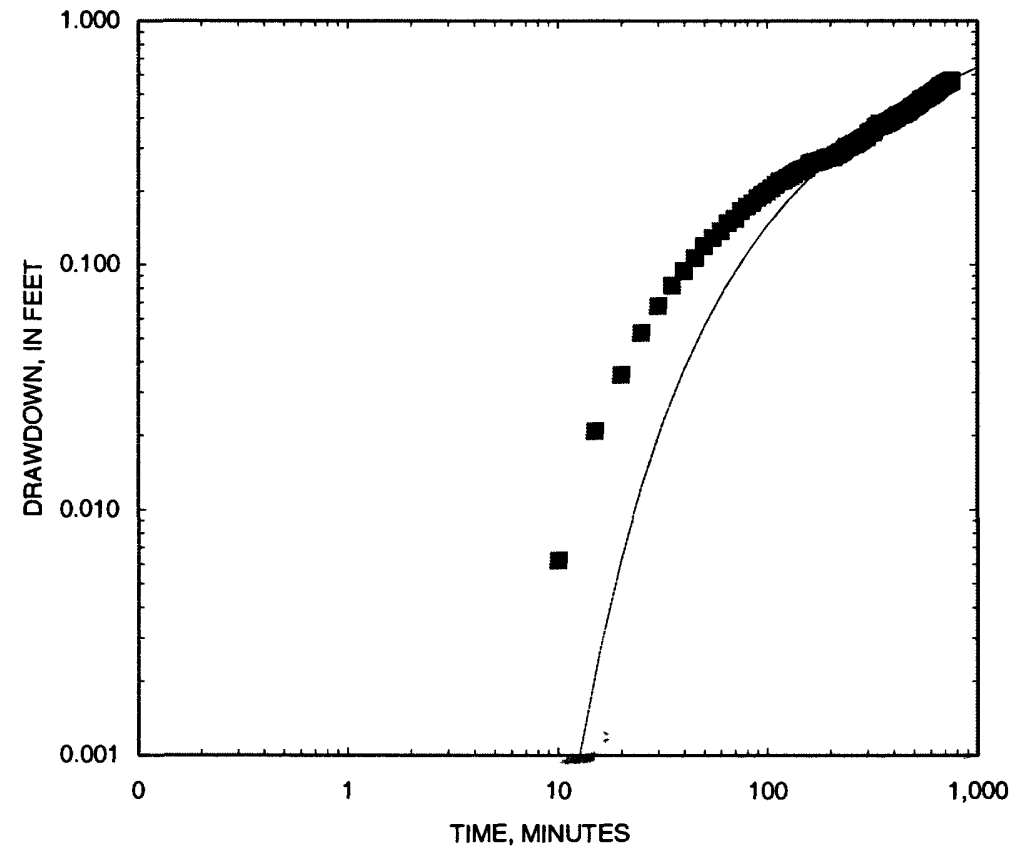

Figure 14. Time-drawdown data and Theis type curve for well AL-65, western Allen County, Ohio. Theis curve represents a transmissivity of 30,700 gallons per day per foot and a storage coefficient of $4.7 \times 10^{-4}$. 


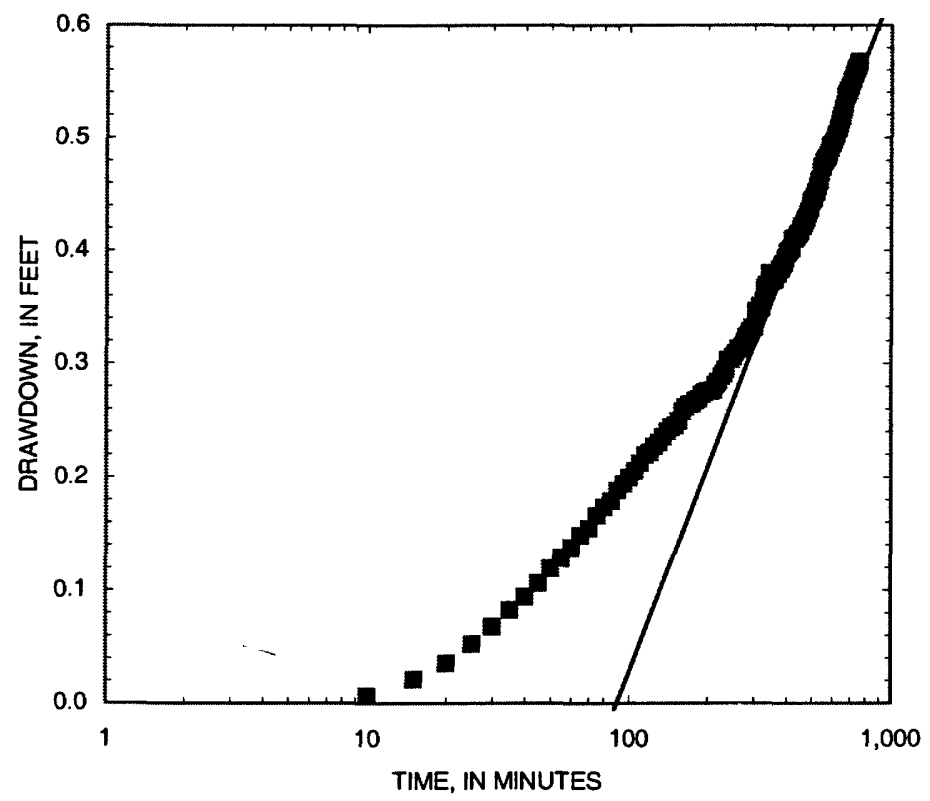

Figure 15. Time-drawdown data and Cooper and Jacob (1946) type curve for well AL-65, western Allen County, Ohio. Transmissivity and storage coefficient are 30,700 gallons per day per foot and $4.7 \times 10-4$, respectively.

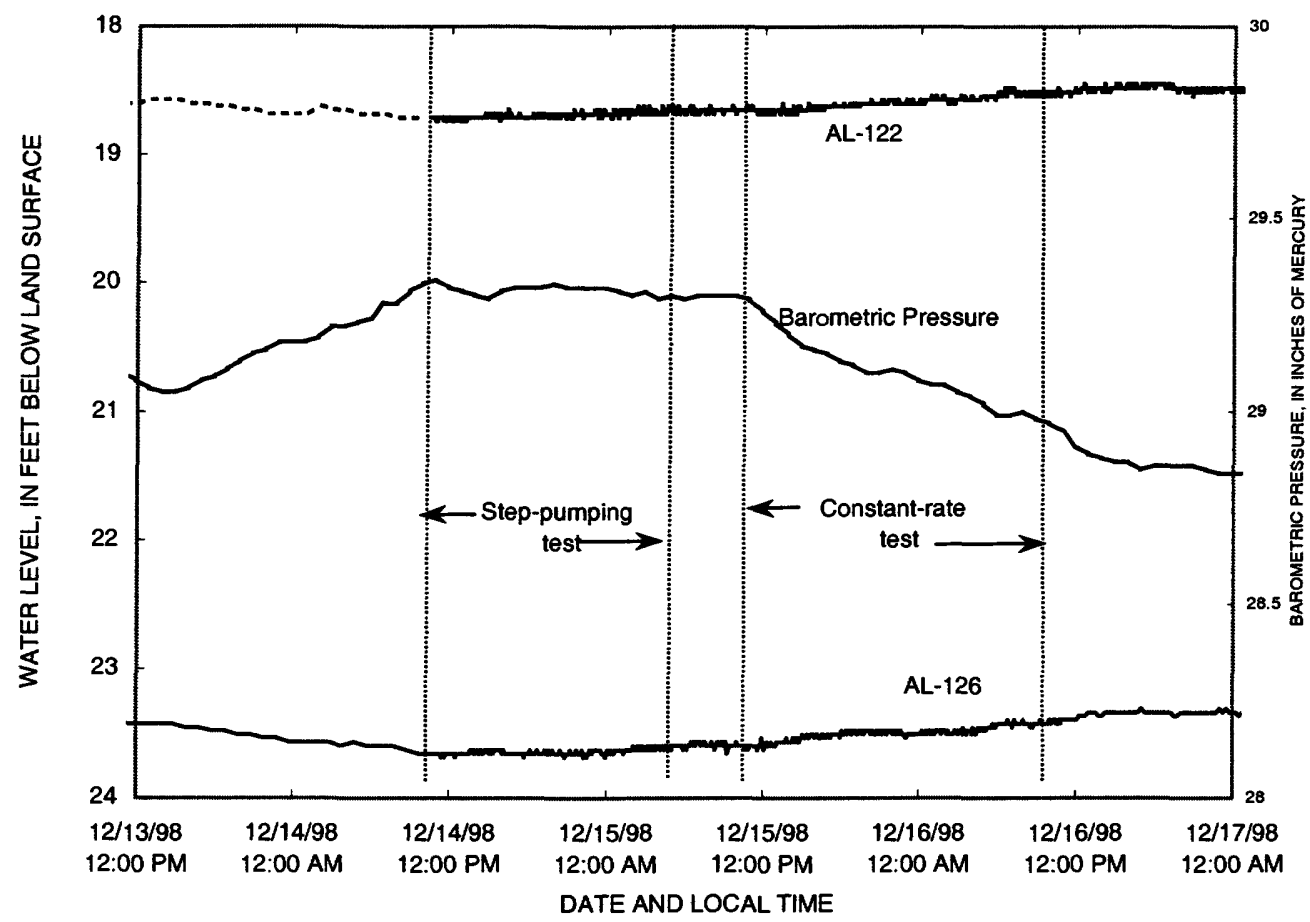

Figure 16. Barometric pressure and water levels for two shallow wells completed in sand lenses within the glacial till, western Allen County, Ohio. Start of constant-rate test was $12 / 15 / 98$ at 10:45 a.m. local time. 


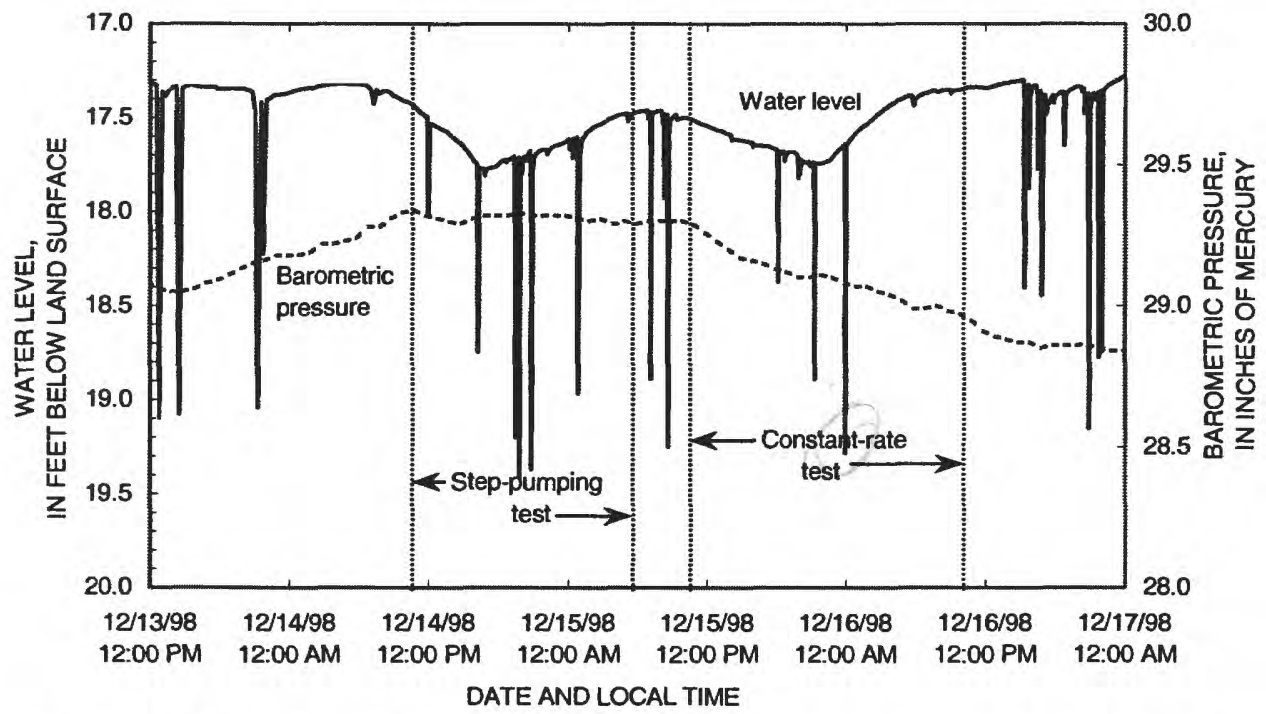

Figure 17. Water levels for well AL-101 and barometric pressure for a period including pumping at well AL-85, western Allen County, Ohio.

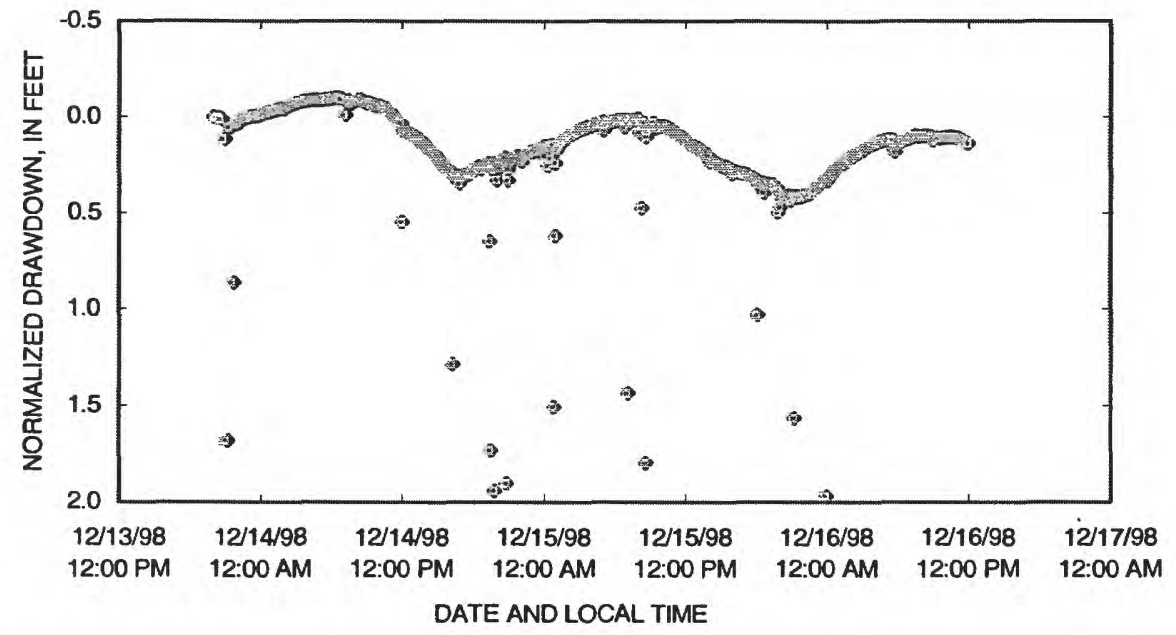

Figure 18. Normalized drawdown for well AL-101 during the step test and constant-rate test at well AL-85, western Allen County, Ohio. Normalized drawdown is equal to water level estimated from effects of barometric pressure minus measured water level. 
is shown in figure 19. The resulting $\mathrm{T}$ and $\mathrm{S}$ $\left(35,750(\mathrm{gal} / \mathrm{d}) / \mathrm{ft}\right.$ and $4.9 \times 10^{-4}$, respectively) are consistent with results from unused monitoring wells (for example, AL-64). A similar analysis was done with water levels from $A L-57$, a carbonate-aquifer well; the resulting $\mathrm{T}$ and $\mathrm{S}$ were $21,530(\mathrm{gal} / \mathrm{d}) / \mathrm{ft}$ and $7.52 \times 10^{-5}$, but the total drawdown due to pumping at AL-85 was only about $0.2 \mathrm{ft}$, and the time-drawdown curve was not amenable to further analysis.

The measured drawdown for wells AL-101 and AL-57 after 750 minutes of pumping at $70 \mathrm{gal} / \mathrm{min}$ was somewhat less than what would be predicted by a distance-drawdown curve (fig. 20) using AL-64 and AL65. Two other domestic carbonate-aquifer wells equipped with continuous recorders, $\mathrm{AL}-55$ and $\mathrm{AL}$ 68 , did not exhibit any obvious effects of pumping at AL-85, although AL-68 is heavily used for a livestock operation and water levels typically vary by more than 80 feet in a single day. No measurable effects of pumping were observed in the manually measured wells surrounding the pumped well. The step-test and constantrate pumping test affected flows from the AL-125 (fig. 21 ), indicating that the source of water flowing from AL-125 likely is the same carbonate aquifer that is tapped by the wells at the proposed well field. The water-quality data from AL-125 (table 2) also are similar to results from the carbonate-aquifer wells in the area. The distance to AL-125 is plotted on figure 20 , and the lowered flow from AL-125 is equivalent to an estimated $0.29 \mathrm{ft}$ of drawdown.

Water quality and hydraulic data collected during this study strongly indicate that the spring (AL125 ) is not a wholly natural feature and that it could be an abandoned well. Springs in Allen County, such as the ones in the area surrounding the proposed well field, were described more than 100 years ago (Winchell, 1874): "Strong mineral springs issuing from the rock occur in various parts of the county [Allen]. . . They are known as white sulphur springs. . One rises with an artesian overflow from a well drilled to a depth of one hundred and twenty-nine feet."

Field observation and interviews with local residents indicate the presence of many springs in the area surrounding the proposed well field, including AL-125 (Kendrick Woods Metro Park spring) that was monitored during this study. Field and laboratory waterquality data and changes in discharge of the monitored spring during the constant-rate aquifer test indicate that

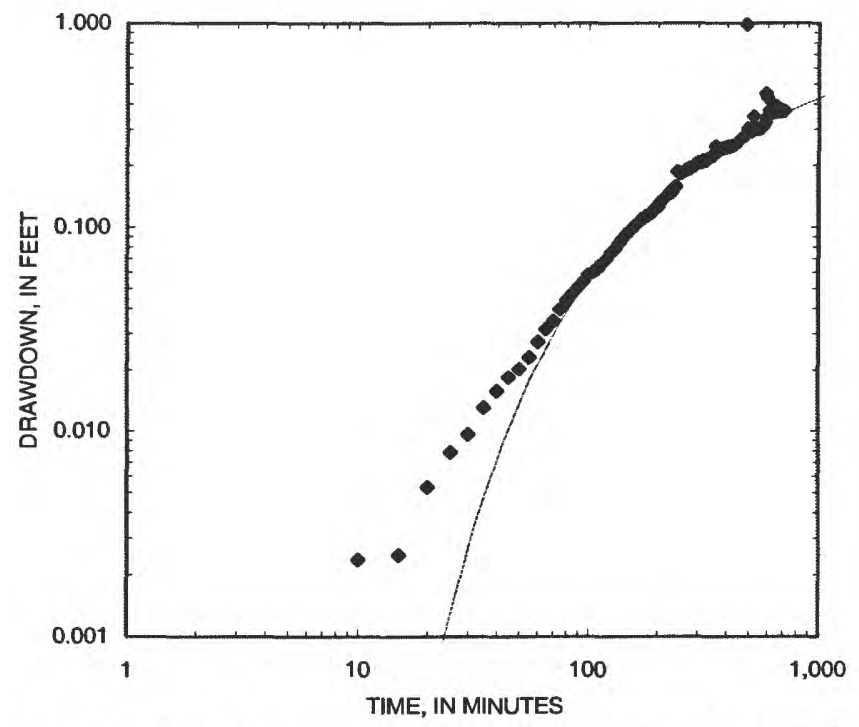

Figure 19. Normalized time-drawdown data for well AL101 during constant pumping at well AL-85, western Allen County, Ohio. Theis type curve is shown as a line on the graph and corresponds to a transmissivity of 35,750 gallons per day per foot and a storage coefficient of $4.9 \times 10^{-4}$. 


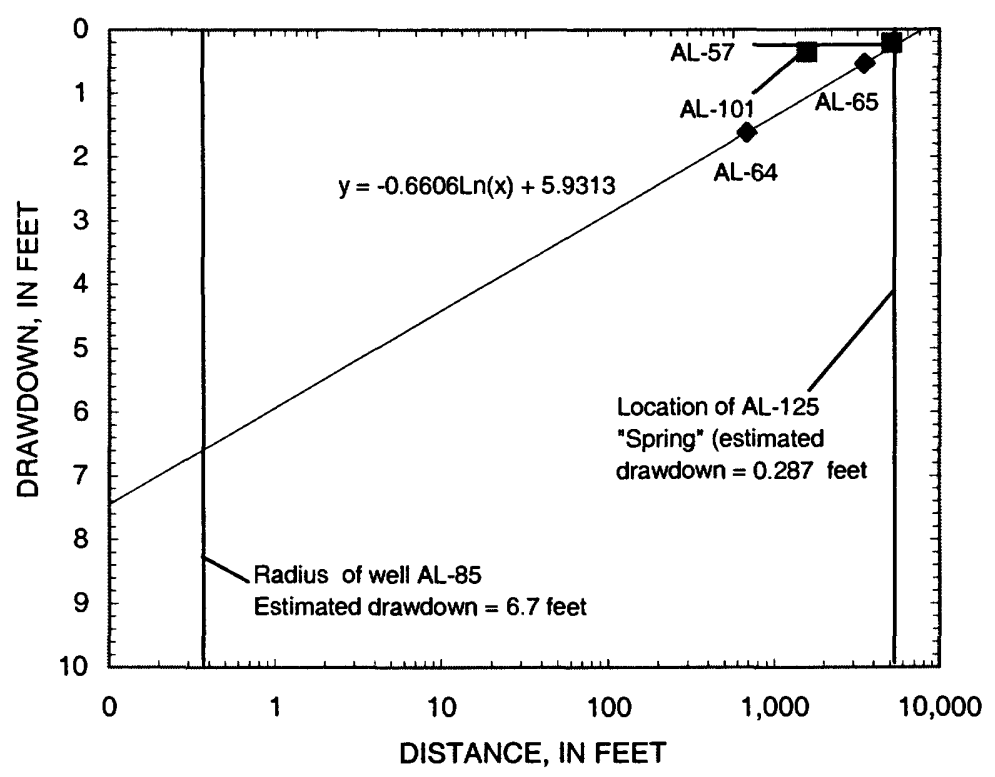

Figure 20. Distance-drawdown graph for constant-rate test at well AL-85, western Allen County, Ohio, at a pumping rate of approximately 70 gallons per minute. Drawdown data are for 750 minutes after pumping started. Regression line is for wells AL-64 and AL-65.

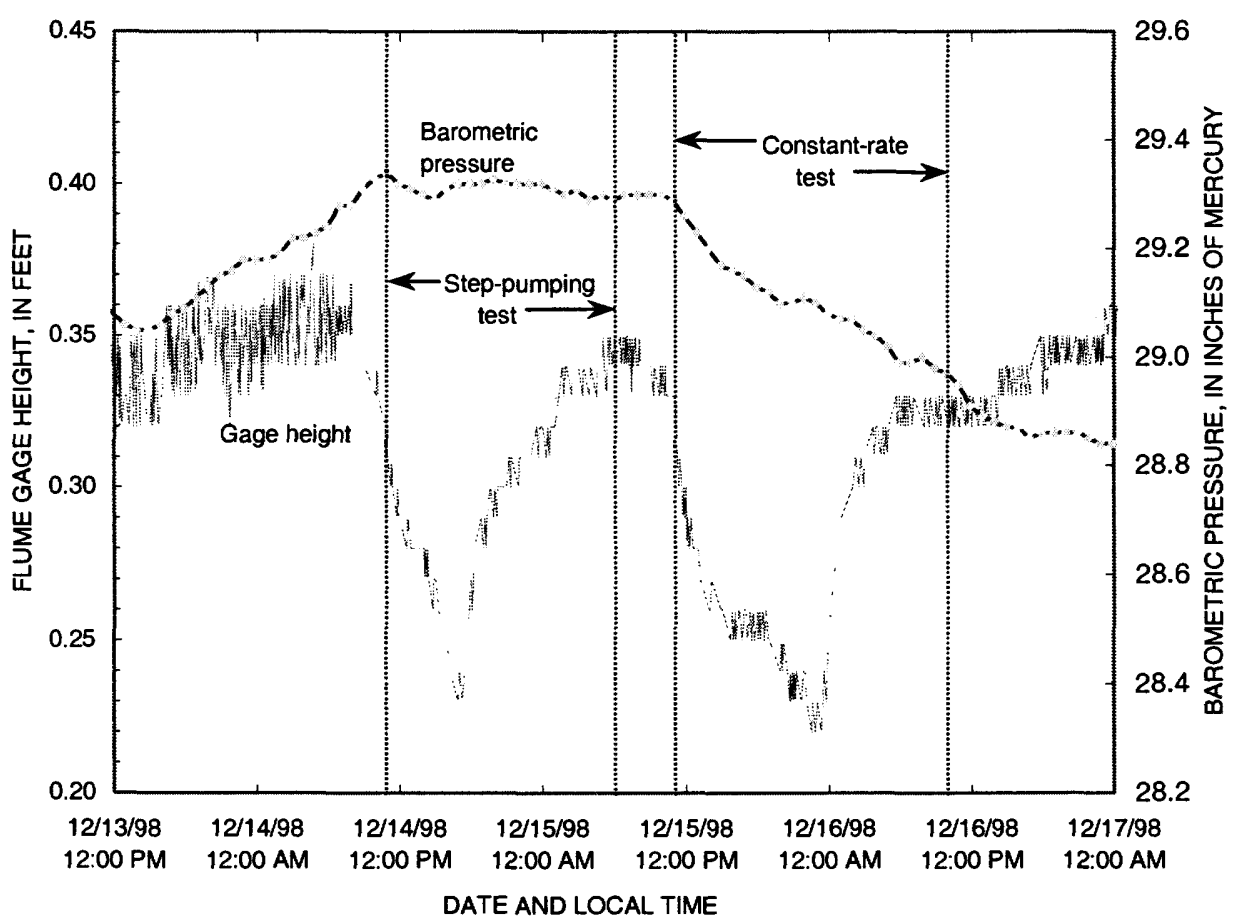

Figure 21. Gage height of flume installed at AL-125 (Kendrick Woods spring) during the step-pumping and constant-rate test at well AL-85, western Allen County, Ohio.
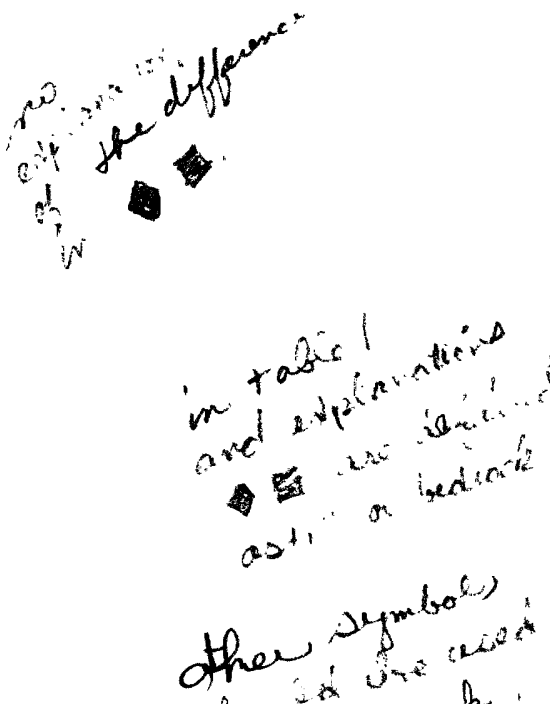

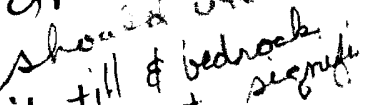
if

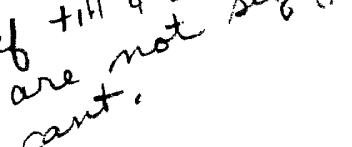

Fig. 2, 5-7 have

valuis expitanation

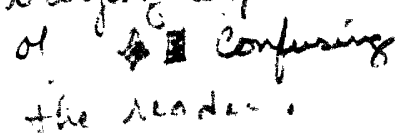


the source of water for this spring is the Silurian carbonate aquifer (probably the Guelph Dolomite) and not a perched ground-water system. The total flow from these springs is unknown but may be important. Longterm monitoring of the flow from this spring would be needed to determine the seasonal fluctuation of flow and potential long-term lowering of hydraulic heads in the confined carbonate aquifer.

Field observations, inspection of USGS quadrangle maps, and landowner interviews revealed several abandoned oil and gas wells within 2 mi of the proposed well field. The presence of abandoned oil wells near the proposed well field may have implications on the long-term quality of water pumped from any proposed production wells. The oil wells were completed in an underlying formation (Ordovician Trenton Limestone; Bownocker, 1903) and likely were cased through the carbonate aquifer. The casing integrity is unknown, but casing degradation is possible and may allow migration of oil or brine into the aquifer.

\section{SUMMARY AND CONCLUSIONS}

The City of Delphos, Ohio, would like to expand its current ground-water supplies with wells completed in the carbonate aquifer in western Allen County, Ohio. Background hydrogeologic data, including surface and borehole geophysics, water-quality samples, and water levels, were collected. Aquifer tests were done at two wells to characterize the hydrologic setting of the carbonate aquifer in the vicinity of a proposed well field.

Water levels and tritium data indicate that the carbonate aquifer in the area of the proposed well field is areally recharged by precipitation, but at a relatively slow rate. Water-level data from paired wells indicate a downward gradient throughout most of the study area except near the Auglaize River, which is a regional discharge area. Only the sand lenses at the base of the glacial till are in direct connection with the carbonate aquifer; most ground water in the sand units is locally perched, but generally is sufficient for domestic supplies. Shallow carbonate-aquifer wells (less than $100 \mathrm{ft}$ deep) are generally less productive than wells completed at depths greater than $190 \mathrm{ft}$ because the carbonate aquifer is morehighly fractured at those depths.

Water-quality data show that glacial-aquifer water is of better esthetic quality and is less variable than carbonate-aquifer water. Water-quality of the Kendrick Woods Metro Park spring is similar to that of the carbonate aquifer.
Results of a variable-rate packer test indicate areal hydraulic connectivity within the lower part of the carbonate aquifer and a weak hydraulic connection between the upper and lower carbonate aquifer. Water levels in glacial-aquifer wells showed no effects of pumping from the lower carbonate aquifer. Flow from a local spring decreased with pumping from the lower part of the carbonate aquifer, an indication that the source of water flowing from the spring is the carbonate aquifer.

Results of the constant-rate aquifer test correlate well with a previous aquifer test. Based on the analysis of water-level data from observation wells and domestic wells monitored during the aquifer test, transmissivities for the carbonate aquifer range from approximately 28,000 to 36,000 (gal/d)/ft and storage coefficients range from $3 \times 10^{-5}$ to $5 \times 10^{-4}$. In general, water levels in wells completed in the glacial aquifer appeared to be unaffected by pumping from the carbonate aquifer. No directional drawdown effects were observed in water levels from observation wells surrounding the pumped well.

Water-quality data and changes in discharge from the Kendrick Woods Metro Park spring during the aquifer tests indicate that the source of water for this spring, and for other springs in the study area, is the lower part of the carbonate aquifer. Numerous abandoned oil or gas wells within the study area could affect the long-term water quality of the carbonate aquifer.

\section{REFERENCES CITED}

Bates, R.L., and Jackson, J.A., eds., 1987, Glossary of geology ( $3 \mathrm{~d}$ ed.): Falls Church Va., American Geological Institute, $788 \mathrm{p}$.

Bennett \& Williams Environmental Consultants, Inc., 1993, Results of test pumping Heidlebaugh Well No. 1: Letter to City of Delphos, $6 \mathrm{p}$.

$\checkmark$ Bownocker, J.A., 1903, The occurrence and exploitation of petroleum and natural gas in Ohio: Geological Survey of Ohio Bulletin 1, 614 p.

$\checkmark$ Carter, M.W., and Moghissi, A.A.,1977, Three decades of nuclear testing: Health Physics, v. 33, no. 1, p. 55-71.

Chow, V.T., 1959, Open-channel hydraulics: New York, McGraw-Hill Book Co., 680 p.

Cooper, H.H., Jr., and Jacob, C.E., 1946, A generalized graphical method for evaluating formation constants and summarizing well field history: Transactions of the American Geophysical Union, v. 27, p. 526-534. 
Eagon and Associates, Inc., 1993, Ground-water evaluation, Heidlebaugh Property, Delphos, Ohio: Consultant's report prepared for the City of Delphos, Ohio, $13 \mathrm{p}$.

$\checkmark$ Fishman, M.J., ed., 1993, Methods of analysis by the U.S. Geological Survey National Water-Quality Laboratory-Determination of inorganic and organic constituents in water and fluvial sediments: U.S. Geological Survey Open-File Report 93-125, 217 p.

$\checkmark$ Fishman, M.J., and Friedman, L.C., eds., 1989, Methods for determinations of inorganic and organic substances in water and fluvial sediments: U.S. Geological Survey Techniques of Water-Resource Investigations, book 5 , chap. Al, 545 p.

$\checkmark$ Francy, D.S., Jones, A.L., Myers, D.N., Rowe, G.L., Eberle, Michael, and Sarver, K.M., 1998, Quality-assurance/ quality-control manual for collection and analysis of water-quality data in the Ohio District, U.S. Geological Survey: U.S. Geological Survey Water-Resources Investigations Report 98-4057, 71 p.

$\checkmark$ Hem, J.D., 1989, Study and interpretation of the chemical characteristics of natural waters ( $3 \mathrm{~d}$ ed.): U.S.

Geological Survey Water-Supply Paper 2254, 263 p.

$\checkmark$ Janssens, Adriaan, 1977, Silurian rocks in the subsurface of northwestern Ohio: Ohio Department of Natural Resources, Division of Geological Survey, Report of Investigations $100,96 \mathrm{p}$.

$\checkmark$ Keys, W.S., and MacCary, L.M., 1971, Application of borehole geophysics to water-resources investigations: U.S. Geological Survey Techniques of WaterResources Investigations, book 2, chap. E1, 126 p.

$\checkmark$ Kostelnick, R.J., 1981, Ground-water resources of Allen County: Ohio Department of Natural Resources map report, scale 1:62,500, 1 plate.

Slater, L.D., Sandberg, S.K., and Jankowski, M., 1998, Survey design procedures and data processing techniques applied to the EM azimuthal resistivity method: Journal of Environmental and Engineering Geophysics, v. 3, issue 4, p. 167-177.

$\checkmark$ Theis, C.V., 1935, The relation between the lowering of the piezometric surface and the rate and duration of discharge of a well using ground-water storage: Transactions of the American Geophysical Union, v. 16, p. 519-524.

Winchell, N.H., 1874, Report on the geology of Allen County: Report of the Geological Survey of Ohio, v. 2, Geology and Paleontology, part 1, Geology, p. 397-403. 